\title{
Desiguais e combinados: índios e brancos no vale do Rio Tibagi - PR na primeira metade do século $X X$
}

Eder da Silva Novak

(UFGD)

Lucio Tadeu Mota

(UEM)

Xokleng e Xetá. A sobrevivência dessas populações depende do cultivo de terras com as roças familiares e coletivas, da venda do artesanato nas cidades próximas, do trabalho em fazendas da região e dos programas sociais desenvolvidos pelos governos federal e estadual.

Apesar das várias tentativas de dominação por parte das frentes de expansão coloniais e capitalistas, e de um processo histórico assimétrico e desigual, as comunidades indígenas defenderam tenazmente seus territórios e mantiveram formas e conteúdos específicos de sociabilidade, portando-se enquanto populações diferenciadas em relação à sociedade envolvente' ${ }^{1}$.

Neste artigo serão abordadas as complexas relações sócio-históricas e socioculturais que permearam o processo histórico de desterritorialização² das populações indígenas no vale do rio Tibagi na primeira metade do século XX. Buscarse-á ir além das explicações oficiais de transformação (aculturação) das populações indígenas em populações rurais, evitando, também, a armadilha da história polarizada que simplifica essas relações entre populações diferenciadas. Destacaremos o protagonismo indígena na luta contra o processo de esbulho de seus territórios e seu empenho na defesa de seus costumes e crenças.

A ancoragem teórica-metodológica que sustenta nossa análise está na reflexão sobre a temática da etno-história feita a partir de sua matriz norte-americana desde a Conferência de História Indígena de Columbus em Ohio - EUA em 1953. Nesta conferência, Ermine Voegelin, apontou para a conjunção de dados advindos de outras disciplinas e enfatizou que a etno-história, implicava no envolvimento de duas outras 
O debate iniciado na Conferência de Columbus sobre as questões relacionadas à história dos índios continuou repercutindo no meio acadêmico americano e teve vazão nas publicações da revista Ethnohistory. A preocupação pela definição do que seria a etno-história foi tema da oitava reunião anual da American Indian Ethnohistoric Conference realizada em novembro de 1960 na Universidade de Indiana. Os trabalhos apresentados foram publicados na Revista Ethnohistory v. 8, no 1 em 1961, e os comentários relativos aos papers ali apresentados foram publicados nesse mesmo ano na Ethnohistory v. 8, no 3. 0 tema foi abordado de várias perspectivas por pesquisadores de diversas áreas, desde o Folklore, passando pela História, Antropologia até a Arqueologia.

Sintetizando o debate ocorrido na Conferência de Indiana pode-se afirmar que não houve consenso sobre as questões ali tratadas. Muito se discutiu se a Etno-História seria: disciplina independente; subdisciplina da história ou da antropologia; uma mera técnica de análise dos dados; fornecedora de dados para outras disciplinas; se estava mais relacionada à História ou à Antropologia; se era uma área nova de pesquisa; se ela comportava a descrição etnográfica de culturas históricas; e se ela deveria dividir-se entre: antes ou depois do contato, dentre outros assuntos.

O acalorado debate não chegou a uma conclusão sobre a etno-história ser uma disciplina acadêmica, mas acomodou os debatedores a um acordo tácito de que ela poderia ser uma metodologia que se valeria de fontes, tais como: tradições orais, etnoconhecimentos, elementos da cultura material, dados linguísticos, dados etnográficos e evidências documentais para estudar as transformações nas sociedades nativas da América (Trigger 1982). Depois, essa ideia expandiu para as sociedades nativas da Oceania e África. Essa foi a posição de maior ressonância entre diversos autores/pesquisadores que participavam da American Society of Ethnohistory e foi a posição adotada por ela.

Com essa distinção de fazer uso combinado de diversas fontes na análise integrada do passado é que a etnohistória pode fornecer resultados mais significativos quando comparada com os resultados da história sustentada apenas em fontes documentais (Carmack 1972:233). Focalizando as fontes documentais, Bruce G. Trigger distingue a etno-história da história pelo fato dela trabalhar com fontes escritas produzidas por agentes externos à sociedade estudada, enquanto que a história lida com fontes produzidas pela própria sociedade em estudo. Dessa forma, requer-se do etno-historiador não só os conhecimentos técnicos e habilidades de um historiador convencional, mas também sólidos conhecimentos etnográficos da sociedade que se estuda (Trigger 1982:9).

Será dentro desses marcos teórico-metodológicos que propomos analisar as ações - de sobrevivência e defesa de seus territórios - que os indígenas do vale do rio Tibagi elaboraram para contrapor as novas estratégias de confisco de suas terras que os governos do Paraná e federal, implementaram com projetos de colonização, estabelecimentos de cidades e vilas, e contra às invasões implementadas pelas populações não indígenas que chegavam às áreas de fronteiras.

Nessa nova etapa histórica, da Primeira República, as populações indígenas tiveram que reformular suas ações e reinventar suas formas de lidar com o poder do Estado. Não era mais o poder do Império com sua política de "catequese e civilização", com as quais já lidavam desde a implantação das Colônias Indígenas em meados 
do século XIX, nessa nova conjuntura teriam que se relacionar com novas estruturas organizacionais laicas. Mais ainda, teriam que se defrontar com as políticas do Estado do Paraná que à época tinha o poder de negociar seus territórios, pois, com o advento da república e a nova Constituição de 1891, os Estados da federação passaram a ter o controle sobre as terras consideradas devolutas ${ }^{3}$.

Esse processo atingiu seu ponto máximo em 1949, quando o governo da União e o governo do Estado do Paraná redefiniram os territórios indígenas em todo o estado. Esse acordo constituiu-se num novo confisco dos territórios indígenas já demarcados pelo Estado do Paraná no início do século, e no confinamento das populações indígenas em pequenas áreas reservadas. Esse confinamento estabeleceu novas relações de dependência institucionalizada com os poderes locais, regional e federal, e levou os indígenas a traçar novas formas de relacionamento com esses poderes e com as populações não indígenas do entorno de seus territórios.

A partir de 1949/50, teve início uma nova etapa de luta pela reterritorialização de áreas perdidas que continua até hoje. A luta dos indígenas, por um lado garantiu a sua existência, mas por outro fez com que eles tivessem que readequar seus modos de vida tradicionais às novas situações. Como afirmam os Kaingang, o wãxi, tempo antigo, se transformou no uri tempo atual.

\section{OS INDÍGENAS NO VALE DO RIO TIBAGI ATÉ OS PRIMEIROS DECRETOS DE DEMARCAÇÃO NO INÍCIO DO SÉCULO XX}

A região do médio rio Tibagi está inserida em uma área mais ampla da bacia do rio Paranapanema considerada de alta densidade arqueológica, tanto de sítios pré-históricos como históricos. Esta região passou a ser documentada desde os primeiros momentos da chegada dos europeus no século XVI. Desse modo ela também pode ser considerada de alta densidade historiográfica.

\section{Ocupação pré-histórica}

A presença humana pré-cabralina dos vales dos rios Paranapanema, Tibagi seus afluentes e regiões adjacentes está discutida em diversos estudos realizados pela arqueologia regional. Todos os estudos identificam nessa região vários trechos de alta densidade de sítios arqueológicos pré-históricos.

O mais antigo deles é o sítio PR SA 14, de tradição Umbu, no município de Curiúva, datado pelo arqueólogo Igor Chmyz em 9.190 anos antes do presente (AP). Outras prospecções foram realizadas nas margens do rio Paranapanema e datadas em oito mil anos.

Essa primeira ocupação de caçadores-coletores, cujos vestígios arqueológicos foram denominados pela arqueologia de Tradição Umbu e Tradição Humaitá, estão datados de 9.000 a 2.000 anos (AP), e são predominantemente artefatos e resíduos resultante de lascamentos em diversos tipos de rochas. 


\begin{tabular}{|c|c|c|c|c|c|}
\hline Data AP & Município ou rio & $\begin{array}{l}\text { Tradição } \\
\text { Arqueológica }\end{array}$ & Sítio & Laboratório & Referencia \\
\hline $9190 \pm 60$ & Curiúva & Umbu & PR SA 14 & Lacivid & Chmyz et al., 2008 \\
\hline $9040 \pm 400$ & $\begin{array}{l}\text { Boa Esperança do } \\
\text { Iguaçu }\end{array}$ & Umbu & Ouro verde & & Parellada, 2005 \\
\hline $8115 \pm 80$ & $\begin{array}{l}\text { Baixo } \\
\text { Paranapanema }\end{array}$ & Umbu & PR NL & & $\begin{array}{l}\text { Chmyz; Chmyz, } \\
1986\end{array}$ \\
\hline $6910 \pm 75$ & Foz do Iguaçu & Humaitá & $\mathrm{PR} / \mathrm{FI} / 21$ & | 4994 & Chmyz, 1983 \\
\hline $6683 \pm 355$ & Cidade Gaucha & Humaitá & José Vieira & Gsy 78 & $\begin{array}{l}\text { Laming-Emperaire, } \\
1968\end{array}$ \\
\hline $6505 \pm 105$ & Foz do Iguaçu & Humaitá & $\mathrm{PR} / \mathrm{FI} / 21$ & SI 5993 & Chmyz, 1983 \\
\hline $6265 \pm 80$ & Foz do Iguaçu & Humaitá & $\mathrm{PR} / \mathrm{Fl} / 21$ & SI 4992 & Chmyz, 1983 \\
\hline $5380 \pm 110$ & Mirador & Humaitá & $\mathrm{PR} / \mathrm{QN} / 1$ & SI 1014 & Chmyz, 1977 \\
\hline $5241 \pm 306$ & Cidade Gaúcha & Humaitá & José Vieira & Gsy 80 & $\begin{array}{l}\text { Laming-Emperaire, } \\
1968\end{array}$ \\
\hline $4065 \pm 75$ & Guairá & Humaitá & $\mathrm{PR} / \mathrm{FO} / 49$ & SI 5045 & Chmyz, 1983 \\
\hline
\end{tabular}

Tabela 1: Sítios arqueológicos datados com mais de 4.000 anos antes do presente (AP) no Paraná. Fonte. Mota 2012

Por volta de 2.000 AP (anos Antes do Presente) outros agrupamentos de pessoas passaram a ocupar a área das atuais bacias dos rios Paraná, Ivaí, Paranapanema, Tibagi, Itararé e seus afluentes. Segundo consta na literatura arqueológica regional, esta foi uma das frentes da ampla expansão dos povos falantes da língua Guarani, que vinha ocupando sistematicamente o território do atual Mato Grosso do Sul e dos canais dos rios Paraguai e Paraná, a partir da bacia dos rios Madeira e Guaporé, em Rondônia. Esses agrupamentos possuíam uma matriz cultural em comum, que assegurava a reprodução e a manutenção de uma estrutura similar em termos linguísticos, socioeconômicos, políticos, religiosos e materiais, e sua cultura material ceramista é conhecida na arqueologia como Tradição Tupiguarani.

Também é em torno de 2.000 AP que as datações mais antigas certificam a presença na região de uma outra tradição ceramista diferente da Tradição Tupiguarani. Ela foi denominada pelos arqueólogos de Tradição Itararé. Muitos pesquisadores a relaciona com as populações Kaingang ${ }^{4}$. 


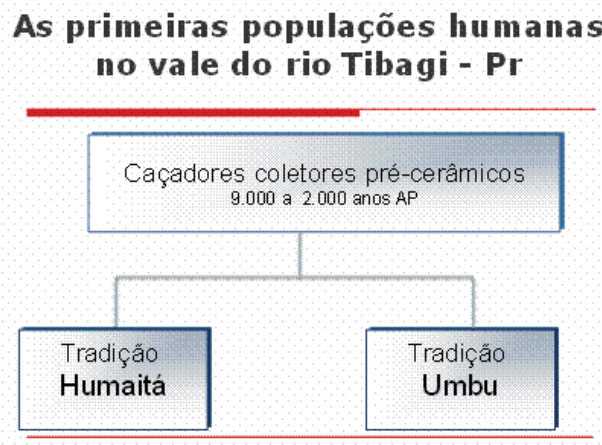

Figura 1. Diagrama das Tradições arqueológicas pré-cerâmicas no Paraná

\section{O contexto histórico}

O contato dos europeus com os grupos indígenas (falantes dos troncos linguísticos Jê e Tupi) ocorreu no início do século XVI com as primeiras expedições portuguesas e espanholas que cruzaram a região rumo ao Paraguai e ao Peru.

D. Alvar Nunez Cabeça de Vaca foi talvez o primeiro europeu a cruzar esses territórios. Da Ilha de São Francisco em Santa Catarina partiu rumo à Assunção no Paraguai. Subiu a Serra do Mar, atravessou o rio Iguaçu e no dia três de dezembro de 1542 chegou "a um outro rio que os índios chamam Tibagi" (Vaca 1987 [1555]:132), provavelmente nas imediações da atual cidade de Tibagi.

No início da década seguinte, em 1551, Diego de Senabria realizou o mesmo itinerário de Cabeza de Vaca. Ainda nesse ano Cristoval de Saavedra, cruzou a região do Paraguai até o porto de São Vicente em São Paulo. No ano seguinte Hernando de Salazar, também fez o mesmo roteiro de Assunção no Paraguai até o porto de São Vicente. Esse roteiro também foi o percorrido por Ulrich Schmidl, nesse mesmo ano. Alguns anos mais tarde, Nuflo de Chaves percorreu todo o rio Tibagi, desde a sua foz no Paranapanema até suas cabeceiras nos Campos Gerais, fez o reconhecimento da região a mando governador do Paraguai Dom Martinez de Irala.

As primeiras décadas do século XVII foram marcadas por uma intensificação das ações dos europeus no Guairá. Foram vários os embates entre os encomiendeiros espanhóis, que buscavam escravizar os índios em suas plantações de mate, e a resistência dos Guarani. Também havia os padres Jesuítas tentando inculcar os valores da sociedade conquistadora aos indígenas. Cruzando os interesses dos encomiendeiros espanhóis e dos padres da Cia de Jesus tivemos os bandeirantes paulistas que vieram ao Guairá em busca de escravos indígenas, metais e pedras preciosas. De uma outra perspectiva tivemos os Guarani e as etnias Jê (Kaingang e Xocleng), fazendo suas alianças, seus acordos e suas guerras. 


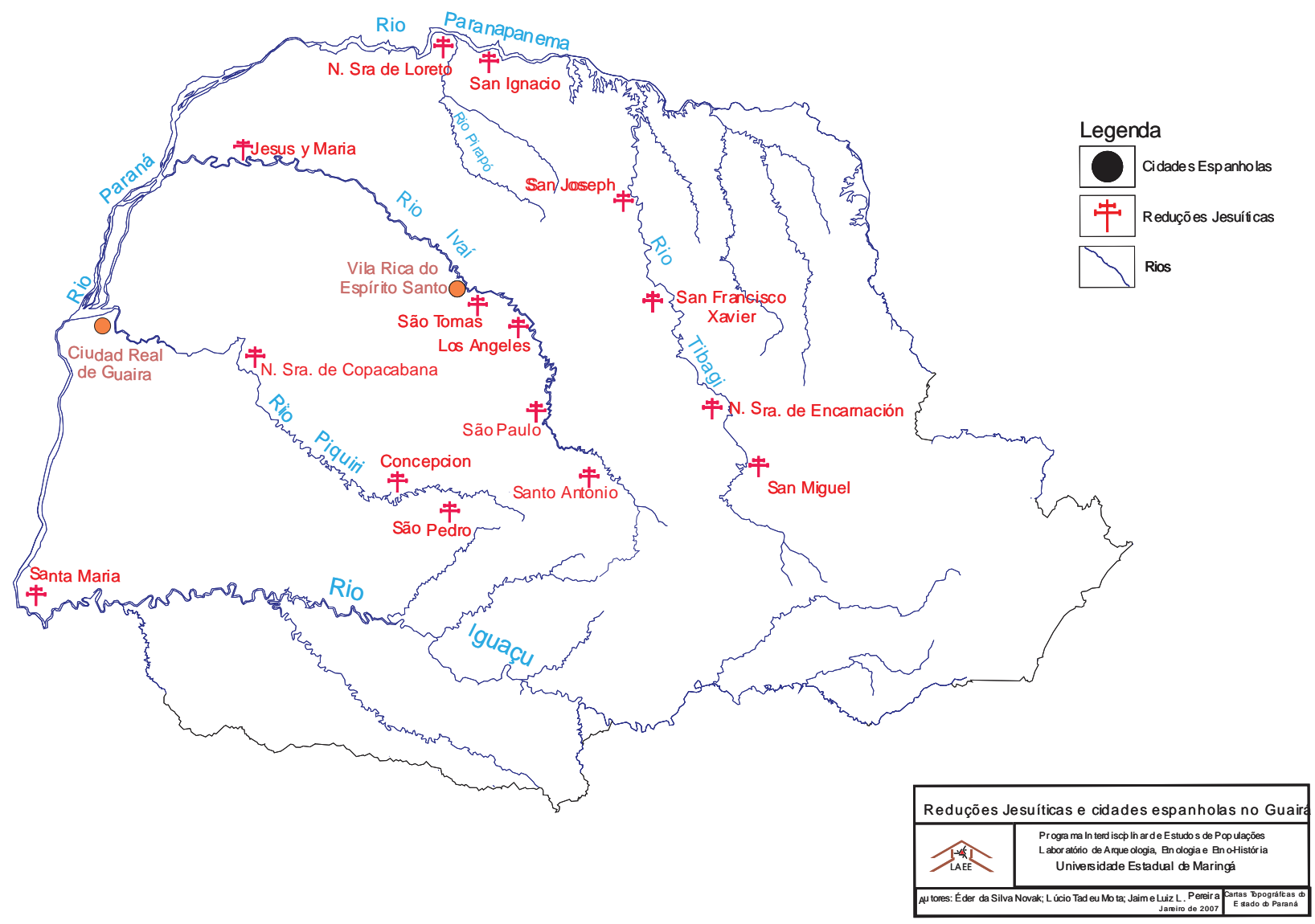

Figura 2. Localização aproximada das Reduções Jesuíticas no Paraná Fonte: Mota 2012

No primeiro quarto do século XVII os padres da Cia de Jesus construíram 17 Reduções nos territórios do Guairá. Instaladas no vale do rio Tibagi estavam: São José, São Francisco Xavier, Encarnacão e São Miguel. Todas foram destruídas pelas invasões dos bandeirantes paulistas no final da terceira década do século XVII.

Se por um lado as bandeiras paulistas foram responsáveis pela destruição das Reduções elas também foram responsáveis pelas primeiras construções militares no vale do Tibagi. Em 1628, Antônio Raposo Tavares e Manoel Preto, ao atacarem o Guairá, construíram um forte ou campo entrincheirado na margem esquerda do Tibagi. 0 padre Simão Maceta se refere a ele como ponto de apoio ou quartel de inverno dos bandeirantes una palisada fuerte de palos, cerca de nuestras aldeas (Carneiro 1942:10). 
Destruídas as Reduções Jesuíticas, as populações indígenas se dispersaram, parte foi para o sul junto com os padres fundar os sete povos das missões, outra parte voltou a reocupar seus os antigos territórios. Mas a região não deixou de ser um atrativo para os paulistas. Em 1651, Fernão Dias Paes Leme, ficou por três anos na região da Serra da Apucarana, e submeteu os caciques da nação Guainá, ancestrais dos Kaingang, levando-os prisioneiros para São Paulo com todo o seu povo (Taunay 1955:167).

Um século mais tarde a região ainda despertava interesse e Francisco Tosi Colombina apresentou aos governantes um plano de ocupação do Tibagi, para ele rico em ouro. Para assenhorear-se das terras ocupadas pelos índios Kaingang, denominados na época de Gentio Guayanãna, Colombina propôs:

E para senhorearse com facilidade dessas terras do Tabagy que agora estão ocupadas do numeroso Gentio Guayanã, (...) um dos melhores meyos hé transportar huns Casaes dos indios mansos, que se achaão nas aldeas de São Paulo, e lá Aldealos (Colombina 1974 1753] :33).

O plano de Colombina não foi levado adiante, mas foi descoberto diamantes em Pedras Brancas, a sudoeste da atual cidade de Tibagi (Mercer 1977 [1934]:23), por ngelo Pedroso e Frei Bento de Santo ngelo. Essa descoberta aguçou a atenção das autoridades e em 1757, o Ouvidor de Paranaguá enviou uma bandeira de 200 soldados para Pedras Brancas com a finalidade de submeter os posseiros. Essa guarda ficou acantonada, no registro de Nossa Senhora do Carmo na foz do rio Capivari no Tibagi, até 1765, onde foi instalado o forte militar de Nossa Senhora do Carmo.

No século XVIII o vale do Tibagi também foi marcado pela passagem das expedições militares de Morgado de Mateus com destino ao Forte Militar de Iguatemi no Mato Grosso. Entre os anos de 1769 e 1774 várias expedições partiram do Porto de São Bento no Tibagi com destino ao rio Ivaí e daí para o Mato Grosso. Conforme Edmundo Mercer, o Porto de São Bento foi uma antiga fazenda situada a margem esquerda do Tibagi a 4 léguas (em torno de $30 \mathrm{Km}$ ) acima da cidade do mesmo nome.

Essas foram ações dos governos coloniais e das populações não indígenas na conquista desses territórios do vale rio Tibagi nos três primeiros séculos de contato.

No século XIX os grandes proprietários estabelecidos nos Campos Gerais procuraram expandir seus domínios. Voltaram sua atenção para a bacia oriental do Tibagi. Em 1794, Antônio Machado Ribeiro (Capitão de Mato do Sargento Mor José Felix da Silva) atravessou o rio Tibagi, acima do rio lapó, e ocupou o lugar onde seria a cidade de Tibagi, no coração dos territórios Kaingang. Em 1812, o próprio José Felix da Silva comandou uma Expedição Militar ao Tibagi. Ele entrou com uma companhia de aventureiros pelo Tibagi e descobriu novos veios de diamantes. Essas descobertas explicam o rápido enriquecimento de José Felix da Silva, dono da Fazenda Fortaleza e de muitas outras na região de Castro e Tibagi (Chichorro 1873:219). John Elliot afirma que os campos do cacique Kaingang Inhonhô, ou de Santa Barbara, a vinte e sete léguas a noroeste de Castro, foram descobertos pelo tenente-coronel José Felix da Silva, dono da fazenda Fortaleza (Elliot 1848:157). 
A partir de 1840, as iniciativas de ocupação das terras da bacia do Tibagi foram levadas adiante por João da Silva Machado - Barão de Antonina. Ele encarregou Joaquim Francisco Lopes e John Henrique Elliot de várias expedições de reconhecimento da região. Conforme Elliot, a $2^{\mathrm{a}}$ expedição, comandada por Joaquim Francisco Lopes e ele como piloto mapista, saiu da fazenda Monte Alegre, pertencente ao Sr. Manoel Inácio do Canto e Silva, atravessou o Tibagi e seguiu rumo norte-noroeste em direção a Serra da Apucarana. No dia 15/9/1846, chegaram ao rio Apucarana nas fraldas da Serra, subiram-na por vários dias até que as condições atmosféricas lhes permitiu vislumbrar toda a região. Elliot afirma que desse local avistou os campos do Inhonhô distante oito a nove léguas a nordeste na margem ocidental do Tibagi.

Um mês depois Lopes e Elliot junto com o Sr. Vergueiro, genro do Barão de Antonina, partiram para os campos do Inhoó. Era uma expedição de 30 pessoas com dois índios como guias. Iniciaram a picada em 21/10/1846 e em 20/11/1846 chegaram a esses campos. Lá o queimaram e os índios responderam com fogos em três lugares diferentes; a norte distante seis a oito léguas, e mais um a nordeste a quatro léguas. Demoram na exploração dessas campinas entremeadas de capões de mato durante 10 dias. No dia 4/12/1846 eles se encontravam nos campos de Inhoó que denominaram de São Jerônimo. Concluíram que eles eram o suficiente para a instalação de um depósito que o Barão projetara, isto é, um entreposto entre o futuro porto do Jataí no Tibagi e Castro. A partir dessa data os territórios do cacique Inhoó nos planaltos a leste do rio Tibagi seriam transformados em um entreposto comercial no caminho para o Mato Grosso e numa fazenda de criação do Barão de Antonina. Fazenda esta que alguns anos depois ele doou ao governo do Império para a criação do Aldeamento Indígena de São Jerônimo.

Enquanto o Barão de Antonina agia no norte do Paraná, na capital do Império se debatia o que fazer com os indígenas. Muitas ideias de como tratar os índios foram formuladas e reformuladas no período imperial. $\mathrm{O}$ gradiente de propostas ia desde a guerra, sugerida por Varnhagen, passava pelas propostas de branqueamento através da miscigenação com as populações brancas, pela catequese e civilização nos aldeamentos religiosos, até a manutenção dos índios com sua cultura em áreas reservadas. Mas prevaleceu a política hegemônica do Império de catequese e civilização dos índios.

Em 1843, o Decreto $n^{\circ} 285$, de 21/06/1843, autorizou a vinda de missionários capuchinhos italianos para trabalharem nas missões de catequese e civilização dos índios, e um ano depois o Decreto $n^{\circ} 426$, de 24/07/1845, regulamentou o serviço das Missões de Catequese e Civilização dos Índios 5 .

Doze anos depois já estavam em pleno andamento os trabalhos de catequese dos índios no vale do rio Tibagi. Atendendo aos interesses do Barão de Antonina ${ }^{6}$ o governo imperial emitiu o Regulamento das colônias indígenas do anno de 1857 - Províncias do Paraná e Mato Grosso em 25/04/1857. Esse regulamento estabeleceu que deveriam ser criadas oito Colônias Indígenas na rota Paraná - Mato Grosso, via rios Tibagi, Paranapanema, Paraná, Samambaia e Ivinhema. Na província do Mato Grosso deveriam ser criadas quatro colônias e no Paraná mais quatro: a de São Pedro de Alcântara defronte da Colônia Militar do Jatahy; Santa Izabel dez léguas abaixo da primeira na confluência dos rios Tibagi e Paranapanema; a de Nossa Senhora de Loreto no lugar da antiga Redução Jesuítica; e a de Santa Thereza na confluência dos rios Paraná e Paranapanema. 
Com isso estaria protegida a rota comercial que o Barão de Antonina estava criando para o Mato Grosso, bem como era o primeiro passo para a apropriação dos vastos territórios indígenas nos vales desses rios com a concentração dos indígenas nas imediações das Colônias.

\begin{tabular}{lllll} 
N & Nome & Localização & Ano de Fundação & Funcionamento \\
\hline 1 & Santa Teresa & Rio Paranapanema no Paraná & 1857 & $1855-1862$ \\
\hline 2 & $\begin{array}{l}\text { Nossa Senhora do } \\
\text { Loreto }\end{array}$ & Rio Pirapó no Paranapanema & 1855 & $1855-1862$ \\
\hline 3 & Santo Inácio & Rio Santo Inácio no Paranapanema & 1862 & $1862-1878$ \\
\hline 4 & Santa Isabel & Rio Tibagi no Paranapanema & 1857 & $\begin{array}{l}\text { Planejada e não } \\
\text { instalada }\end{array}$ \\
\hline 5 & São Pedro de Alcântara & Rio Tibagi em frente a Colônia Militar do Jatai & 1855 & $1855-1895$ \\
\hline 6 & São Jerônimo & Campos do cacique Kaingang Inhoó & 1859 & Não planejada mas \\
instalada 1859-1889
\end{tabular}

Tabela 2: Colônias Indígenas do Império nos rios Paranapanema e Tibagi. Fonte: Mota 2012

A Colônia indígena de São Pedro de Alcântara foi a maior da província e a que teve maior duração. Planejada para abrigar os índios Kayowá também abrigou vários grupos Kaingang que viviam no vale do rio Tibagi e em outras localidades nos vales dos rios Ivaí e Piquiri. Iniciada em 1855 ela funcionou até a morte do Frei Timóteo de Castelnuovo em 18/5/1895. Ele morreu com 72 anos de idade e 40 de missionário na Colônia Indígena, com sua morte chegou ao fim a colônia implantada em 1855. Alguns grupos Guarani e Kayowá permaneceram em seus tekoha7 nas proximidades sul da Colônia, e os grupos Kaingang ficaram aldeados a montante da mesma. Uma grande parte dos Guarani se deslocaram para seus tekoha nas margens do rio Paranapanema e do rio das Cinzast. E os Kaingang que ali viviam foram para o aldeamento de São Jerônimo ou se deslocaram para seus territórios na região da serra da Apucarana onde mais tarde foi criado o posto indígena Dr. Xavier da Silva, posteriormente posto Apucarana.

Não previsto no Regulamento das colônias indígenas do anno de 1857 - a Colônia Indígena de São Jerônimo da Serra teve que ser criada em 17/06/1859, devido ao levante dos Kaingang na região. Ela foi instalada no antigo território Kaingang apossado pelo Barão de Antonina que os nominou de fazenda São Jerônimo, que em seguida a doou ao Império. A planta da colônia foi traçada por John Elliot e seu primeiro Diretor foi Joaquim Francisco Lopes. Essa Colônia teve como primeiro religioso Frei Mathias de Gênova, e em seguida assumiu Frei Luiz de Cemitille.

O ano de 1875 foi marcado por um fato importante que sinalizou o início da ocupação das terras da Colônia Indígena de São Jerônimo por populações não indígenas. Em 4/9/1875, o Governo Imperial, pelo aviso da Fazenda, $n^{\circ} 150$, autorizou o governo da Província a conceder títulos de arrendamento às famílias não índias residentes no Aldeamento, conforme a solicitação de Frei Luiz de Cemitille (Cavalcanti 1924:10). 
O processo de ocupação das terras indígenas dos campos do Inhoó, pelos não indígenas, continuou agora nas terras "doadas" aos Kaingang pelo Barão de Antonina. Em 4/2/1882, a Câmara Municipal de Tibagi, liderada por Telêmaco Borba, sugeriu a criação de um novo Aldeamento na margem esquerda do Tibagi na barra do rio Bello, extinguido o da localidade de São Jerônimo. O historiador Ruy Wachowicz afirma que o objetivo de Telêmaco Borba e de seus seguidores era tentar apoderar-se das terras indígenas do aldeamento de São Jerônimo (Wachowicz 1987:60).

Com o fim do Império, as Colônias Indígenas foram desarticuladas, mas a região compreendida pela bacia hidrográfica do rio Tibagi era ocupada por diversos grupos de Kaingang, Guarani e Kayowá, que mantinham seus modos de vida e exerciam suas políticas estratégicas para fazer frente às ações do governo e das frentes de expansão, que chegavam à região. Durante toda a existência das Colônias os indígenas procuraram utilizar dos recursos nelas investidos. Solicitaram ferramentas, objetos diversos e mesmo dinheiro como pagamento por serviços prestados. Ao mesmo tempo, mantinham uma política de confronto com os moradores brancos vizinhos e pressionavam os governantes locais para assegurarem parcelas de seus territórios.

\section{DOS DECRETOS DEMARCATÓRIOS DO INÍCIO DO SÉCULO XX ATÉ O ACORDO DE 1949}

Neste contexto de fim do Império e fim da política da catequese e civilização implementadas nas Colônias Indígenas, de início da República e da gestão das "terras devolutas" pelos governos estaduais, as comunidades indígenas passaram a reivindicar a demarcação de suas terras. Na perspectiva do governo do estado do Paraná a questão indígena seria resolvida com a demarcação de uma área e a concentração de todos os grupos nela. Essa estratégia foi o que norteou os decretos demarcatórios de terras no estado do Paraná no começo do século XX.

Mas os Decretos de demarcação de territórios indígenas do início do século XX não podem ser tratados apenas como um projeto político do estado paranaense para atender as elites locais e as frentes colonizadoras. As solicitações de demarcações partiram também dos próprios grupos indígenas, que percebendo o contexto ao seu redor, passaram a reivindicar a propriedade de suas terras. $\mathrm{Na}$ análise da política indigenista de demarcação das terras para os índios se torna evidente a política indígena na luta por seus territórios tradicionais. De um lado, o governo do estado e as companhias de colonização loteando vastas áreas e formando diversos núcleos coloniais. Do outro, os indígenas traçando suas estratégias em defesa dos seus interesses.

Enquanto Lei estadual n ${ }^{\circ} 853$, de 22 de março de 1909, reafirmava as violências cometidas contra os indígenas:

Art. 9. ${ }^{\circ}$ O Governo, respeitando os principios de humanidade e civilização, deve procurar, por todos os meios, impedir que continue o massacre dos nossos selvicolas, responsabilisando as autoridades que se tornarem indiferentes ás transgressões da lei de protecção. (Arquivo Público do Paraná. Curitiba. Lei N. 853, de 22 de março de 1909).

O então governador do Paraná Xavier da Silva, em mensagem ao Congresso Legislativo em 1911, reproduz seu discurso feito na instalação do SPILTN - Serviço de Proteção aos Índios e Localização dos Trabalhadores 
Nacionais - no Paraná em 1910, enfatizando a ausência de conflitos e o tratamento benevolente para com os índios no estado.

O eminente Dr. Rodolpho Miranda, quando Ministro de Estado da Agricultura, Industria e Commercio, cogitou entre muitos outros problemas, da catequese, ou proteção aos índios, e localisação de trabalhadores nacionaes, fazendo baixar, para isso, o Regulamento de 20 de junho de 1910. O seu objectivo é respeitar os costumes e religião dos indigenas e, sobretudo, defender as terras que ellesoccupam, demarca-las, garantindo-lhes a sua posse. Podese afirmar que no Estado não se registram actos de atrocidades ou perseguição contra os selvicolas, antes são recebidos em toda parte com carinho e benevolencia. (Mensagem dirigida ao Congresso Legislativo do Estado do Paraná, em primeiro de fevereiro de 1911, pelo presidente do Estado, Dr. Fernando Xavier da Silva. p.11).

Além de ressaltar a atuação do Estado na demarcação das terras ocupadas pelos indígenas, ele apresentou uma lista das áreas reservadas aos índios no Paraná nos primeiros anos do século XX.

\begin{tabular}{|c|c|c|}
\hline Decreto/Data & Descrição & Fonte \\
\hline $\begin{array}{l}\text { Decreto } n^{\circ} 6 \\
(5 / 7 / 1900)\end{array}$ & $\begin{array}{l}\text { Fixa as terras dos Kaingang dos aldeamentos de São Jerônimo e São Pedro de } \\
\text { Alcântara nas terras devolutas sitas entre os rios Tibagi, Apucarana, Apucaraninha e } \\
\text { a serra do Apucarana no município do Tibagy }\end{array}$ & $\begin{array}{l}\text { Estado do Paraná } \\
\text { - Leis, Decretos e } \\
\text { Regulamentos de } 1900\end{array}$ \\
\hline $\begin{array}{l}\text { Decreto } n^{\circ} 6 \\
(31 / 7 / 1901)\end{array}$ & $\begin{array}{l}\text { Fixa as terras dos Kaingang do cacique Jembre em Guarapuava. "Fica reservada para } \\
\text { o estabelecimento da tribu indígena de Coroados, ao mando do cacique Jembre, e } \\
\text { a outras tribus que quizerem alli se estabelecer, uma area de terras comprehendida } \\
\text { nos limites seguintes: A este o rio das Cobras. A oeste o Rio União. Ao sul a picada } \\
\text { velha, que do Xagu vae a colônia da Foz do Iguassu e ao norte a picada nova que } \\
\text { demanda a mesma colônia". }\end{array}$ & $\begin{array}{l}\text { Estado do Paraná } \\
\text { - Leis, Decreto e } \\
\text { Regulamentos de } 1901 .\end{array}$ \\
\hline $\begin{array}{l}\text { Decreto } n^{\circ} .8 \\
(9 / 9 / 1901)\end{array}$ & $\begin{array}{l}\text { Fixa as terras dos Kaingang chefiados pelos caciques Paulino Arak-xo e Pedro Santos } \\
\text { nas margens do rio Ivaí, entre os rios do Peixe ou Ubasinho e o Ribeirao do Jacaré e } \\
\text { o cume da Serra da Apucarana no município de Guarapuava. }\end{array}$ & $\begin{array}{l}\text { Estado do Paraná, } \\
\text { Leis, Decretos e } \\
\text { Regulamentos de } 1901\end{array}$ \\
\hline $\begin{array}{l}\text { Decreto } n^{\circ} \cdot 64 \\
(2 / 3 / 1903)\end{array}$ & $\begin{array}{l}\text { Fixa as terras dos Kaingang do cacique Antonio Joaquim Cretã, de Palmas. "Fica } \\
\text { reservada para o estabelecimento de tribus indígenas as terras occupadas pelas } \\
\text { cabidas do cacique Cretã, com as seguintes divisas: a partir da cabeceira do Ribeirão } \\
\text { do Lageado Grande a cabeceira do Ribeirao Palmeirinha, e por estes dous rios abaixo } \\
\text { ate o Iguassu que será divisa norte, respeitado os direitos de terceiros". }\end{array}$ & $\begin{array}{l}\text { Estado do Paraná } \\
\text { - Leis, Decretos e } \\
\text { Regulamentos de } 1903\end{array}$ \\
\hline
\end{tabular}

Tabela 3. Decretos do Governo do Paraná reservando terras às populações indígenas no Paraná. ${ }^{9}$ Fonte: Os autores

Os terrenos definidos para os índios, enunciados no discurso de inauguração da Regional do SPILTN no Paraná e reafirmados na mensagem de governo aos deputados estaduais, no início da legislatura de 1911, eram do interesse das elites locais, pois, ao fixar onde os indígenas deviam permanecer, também definiam onde não podiam. Com isso liberava terras para serem negociadas. As elites estaduais vislumbravam não apenas o que se podia ganhar com o negócio das terras, mas calculavam também os valores das imensas reservas de madeira que propiciariam bons lucros. 
A estratégia do governo do Paraná de concentrar todos os grupos indígenas do vale do Tibagi na área entre os rios Apucarana, Tibagi e Apucaraninha conforme o Decreto $n^{\circ} .6$ de 5/7/1900, não surtiu efeito. Os Kaingang que viviam nos aldeamentos em torno de São Jerônimo não abriam mão de seus territórios. Persistiram na reivindicação de suas terras junto às autoridades locais e federais. Neste contexto, com a intervenção do recém criado SPI - que passou a desenvolver o papel de poder tutelar no controle da questão indígena no país - foi criada a povoação indígena de São Jerônimo, através do Decreto Federal $\mathrm{n}^{\circ} .8941$, de 30 de agosto de $1911^{10}$. Dessa forma alguns grupos Kaingang garantiam uma parcela de seus territórios na margem direita do Tibagi, enquanto outros grupos que viviam na margem esquerda começaram a se concentrar na área demarcada entre os rios Apucarana e Apucaraninha na margem esquerda.

Em 1912, a demarcação das terras reservadas aos indígenas novamente foi apresentada pelo Congresso Legislativo do Paraná, através da Lei $n^{\circ}$. 1.198, de 16 de abril de 1912.

Art. 1. ${ }^{\circ}$ Fica o Poder Executivo autorisado a proceder da maneira que julgar mais conveniente, no sentido de proteger os interesses dos indigenas quanto ás terras que lhes tem sido concedidas.

Parag. Unico. Para este fim o Governo poderá mandar medir e demarcar as areas de terras devolutas que julgar convenientes.

Esta Lei demonstra que as áreas concedidas aos grupos indígenas ainda não estavam asseguradas e que o poder executivo, como melhor julgasse, deveria proceder de alguma maneira a garantir as terras aos índios, através da medição e demarcação das terras. As populações indígenas se mostravam preocupadas com a questão de suas terras, notando a aproximação dos colonos, cada vez mais em quantidades maiores.

E ainda havia solicitações de demarcação de terras dos indígenas que ainda não tinham sido atendidas. No vale do Tibagi o Governo do Paraná ainda teve que regulamentar as terras dos índios Kaingang na Serra do Cadeado pelo Decreto 591 de 17/08/1915, onde fixou os limites das terras dos Kaingang estabelecidos nos toldos de Faxinalsinho, Palmital e Faxinal do Cambara (Cf. Estado do Paraná - Coleção de Decretos e Regulamentos de 1915).

Importante ressaltar que os grupos indígenas, mesmo após as demarcações de terras, não estavam vivendo apenas nas áreas demarcadas. O SPI em diligencia feita no vale do Rio Tibagi em 1910 indicou a presença de diversos grupos Guarani, Kayowá e Kaingang vivendo em territórios fora das áreas demarcadas pelos decretos do início do século ${ }^{11}$.

As ações dos indígenas no norte do Paraná chamavam a atenção das autoridades políticas estaduais que classificavam os indígenas como arredios e que viviam de forma isolada. Em 1920 foi apresentada pela assembleia estadual do Paraná, a Lei ${ }^{\circ}$. 1918, de 23 de fevereiro, pedindo o fim da povoação indígena de São Jerônimo e sua elevação à categoria de município, desmembrando-se da comarca de Tibagi. Nesse período, a área onde era o antigo aldeamento, já estava lotada de posseiros e colonos brancos.

Nesse momento, autoridades políticas do Paraná e representantes do SPI promoviam um intenso debate sobre a extinção da povoação indígena de São Jerônimo. O deputado federal Arthur Martins Franco desenvolveu uma acentuada campanha contra o SPI solicitando a extinção desse órgão e da povoação indígena de São Jerônimo. 
Ele alegava que os índios deveriam ser livres para tratar diretamente com os brancos, pois considerava os Kaingang dominantes da língua portuguesa e conhecedores da moeda, portanto, poderiam realizar contratos e empreitadas de serviços sem a mediação do órgão tutelar.

As discussões entre representantes do SPI - que não aceitavam a decisão do estado do Paraná em criar municípios onde existiam terras indígenas - e políticos e líderes locais - que defendiam os interesses da ocupação do território paranaense, desmerecendo os índios - se prolongaram durante a década de 1920.

Vários foram os discursos proferidos no Congresso Legislativo, pelo deputado Arthur M. Franco, atacando as ações do SPI em todo o território do Paraná. Esses ataques eram rebatidos pelos representantes do SPI, que davam explicações e devolviam acusações ao congressista. Em 1922, Luiz Bueno Horta Barbosa, então diretor interino do SPI no Paraná elaborou um extenso relatório comentado as ações do SPI no estado, sobretudo na povoação indígena de São Jerônimo, rebatendo as críticas do deputado Arthur M. Franco. Este relatório foi publicado pelo Diário de Curitiba, em 13 de setembro de 1922.

Das outras machinas diz o articulista que servem apenas de inofensivos modelos, o que equivale a dizer que absolutamente nao trabalham. Mas, certamente arrependido da injustiça que nos fez com tal affirmativa, acrescenta: 'digo mal: produzem quiréla'. mas apesar dessa expontanea rectificação sua senhoria ainda continuou a dizer mal, porque, estando a se referir a um moinho de fubá e a machinismos para fabricar farinha, o assombroso seria se o primeiro não produzisse quiréla, e impossível é que as segundas a produzam.

Na verdade, porem, o que há, é muita leviandade em todas estas accusações. Compilou-se, às cégas e às tontas, o que se foi encontrado pelo caminho. A não ser assim, como se poderia explicar que depois de tantos desastres, o articulista juntasse mais o de dizer que: 'do exposto conclue-se que a Inspectoria dos Indios interpreta o Regulamento a seu bel prazer'. Não, mil vezes não! Nem a Inspectoria de Indios, nem nenhuma outra repartição publica federal poderá nunca interpretar, nem aplicar o seu regulamento e as leis do Paiz, a seu bel prazer. Referir-se a tal coisa, como se ella fosse possivel e praticavel, é revelar a mais profunda e absoluta ignorância do mechanismo administrativo que nos rége. Que despesa pode realizar, e pagar com dinheiros publicos, uma repartição que não cingisse a seguir o seu Regulamento e começasse a fazer serviços segundo o critério pessoal do seu chefe? (Diário de Curitiba 13/09/1922).

Ainda em 1922, através da Lei $n^{\circ}$. 2.113, o governo do Paraná procurou entendimento com a União para tratar da extinção da povoação indígena de São Jerônimo, apresentando ainda alternativas para os bens patrimoniais de sua guarda.

Art. 1. Fica o Poder Executivo autorizado a se entender com o Governo Federal no sentido de ser extincta a actual Povoação Indigena de São Jeronymo.

Parag. unico. Uma vez conseguida a extincção da referida Povoação Indigena, o Poder Executivo entrará em accordo com a União, no sentido de serem vendidos, alugados ou arrendados á municipalidade, ou a particulares, aos proprios nacionaes alli existentes como, sejam a serraria e casas de madeira pertencentes ao governo.

Art. 2. O Poder Executivo providenciará no sentido de ser demarcadas a área actual e effectivamenteameaçadas pelos indigenas de São Jeronymo ou a transferir as famílias alli existentes para as terras da Apucarana, pertencentes aos mesmos indigenas.

Conforme Artigo 2 acima, novamente o governo do estado cogitava transferir os grupos Kaingang de São Jerônimo para as "terras da Apucarana", reservadas em 1900. Nova tentativa de encaminhar aqueles índios para 
a margem esquerda do rio Tibagi, classificando os indígenas de São Jerônimo como pertencentes aos mesmos que estavam nas terras da Apucarana, não reconhecendo as diversidades específicas de cada grupo, atribuindo uma falsa homogeneização aos grupos indígenas.

Em 1924, o deputado Arthur Martins Franco voltou a criticar severamente a atuação do Serviço de Proteção aos Índios (SPI), durante audiência na câmara federal, informando que os índios do norte do estado ameaçavam a população daquele local. Franco desejava a extinção do SPI, argumentando que defendia uma minoria de índios e colocava em risco a vida da maioria dos colonos, e, ainda afirmava que os Kaingang já dominavam a língua portuguesa, conheciam a moeda e poderiam viver sozinhos, sem o órgão tutelar.

Rebatendo, em 1924, Luiz Bueno Horta Barbosa publicou no Jornal do Commércio, em 30 de dezembro, uma carta aberta ao deputado Arthur Martins Franco, novamente rechaçando as críticas e fazendo acusações ao congressista.

Limitarei a presente resposta a dous topicos do alludido discurso. Refere-se, o primeiro ao qualificativo de violento e illegal que deu o acto do Governo do Paraná, de designar a villa de S. Jeronymo para séde do municipio do mesmo nome; o segundo à exposição que fiz do procedimento pelo qual V. Ex., tirou para si um tracto de terras da propriedade doada pelo Barão de Antonina aos índios daquella região.

Entrando, pois, no primeiro ponto, explicarei a V. Ex, que o que eu classifiquei de acto de expropriação violenta e illegal praticada pelo Governo do Paraná, não foi a da creação do municipio de S. Jeronymo, mas sim o da implantação da séde desse municipio no interior da propriedade dos indios. E isso foi praticado com infracção de uma lei do proprio Estado, conforme indiquei na pg. 8 do opusculo a que V. Ex. parece ter querido responder, e acarretou o procedimento da municipalidade de formar o patrimonio territorial, que por lei devia possuir a localidade antes e como condição de ser elevada a séde de municipio, à custa da propriedade dos indios.

É por estas e outras que encontramos difficuldades em aceitar logo sem maior exame, (...) as affirmações de V. Ex. relativas ao inteiro desinteresse de seus actos em S. Jeronymo. Não é extranho a esta nossa resistencia a admittir semelhante ponto de fé, a lembrança de temos visto referência a uma escriptura de venda de terras de S. Jeronymo, na qual o nome de V. Ex. figurava como o do outorgante (Jornal do Commércio 30/12/1924).

O governo do Paraná e políticos a ele ligados, junto com os interesses comerciais de grandes proprietários de terra, nunca aceitaram a criação da povoação indígena de São Jerônimo. Por todos os meios procuraram desqualificar as populações indígenas que ali viviam e desacreditar o trabalho desenvolvido pelo SPI. São muitos os discursos como os Arthur Martins Franco e são inúmeros os documentos gerados pela administração do SPI na Inspetoria Regional instalada em Curitiba tratando da questão até 1949 quando se dá um desfecho parcial e abre uma nova etapa na luta dos Kaingang pelos seus territórios ${ }^{12}$.

\section{GRANDE ESBULHO (ACORDO) DE 1949}

A história da desterritorialização dos indígenas no Paraná ainda ganharia um novo episódio em 1949 durante o governo de Moisés Lupion. Através de um acordo entre os governos da União e do estado, as terras indígenas já demarcadas no início do século $\mathrm{XX}$ foram reduzidas com o objetivo de atender as demandas do avanço da colonização e a consequente liberação de novas áreas para as frentes de expansão. 
Os argumentos empregados para justificar o esbulho dos territórios indígenas foram aqueles contidos nos discursos do deputado Arthur M. Franco e repetidos incessantemente por todos interessados em abocanhar parcelas desses territórios: "de que os índios não eram mais índios", ou de que "os índios não precisavam de tanta terra, pois não trabalhavam". Operando nesta baliza de que os "índios já eram ou deveriam ser trabalhadores nacionais", o governo definiu o critério de cálculo para uma nova delimitação dos territórios indígenas no Paraná. Definiu que bastava 100 hectares de terras para cada família de cinco pessoas, mais 500 hectares para abrigar um Posto Indígena que seria a sede administrativa do SPI em cada área. Dentro desses parâmetros o governo federal fez um acordo com o governo do Estado do Paraná e reduziu quase todos os territórios indígenas no estado.

A comparação entre as áreas definidas pelos decretos de delimitação e as áreas definidas no acordo de 1949 demonstra como a partir desta data foram usurpadas grandes parcelas dos territórios indígenas do vale do rio Tibagi.

\section{Os territórios do cacique Inhoó - Terra Indígena de São Jerônimo e Barão de Antonina}

Na primeira década do século $X X$, na margem direita do rio Tibagi nas proximidades onde se situava a Colônia Indígena (Império) mais tarde Povoação Indígena São Jerônimo (República), permaneciam grupos Kaingang habitando seus tradicionais Emás ${ }^{13}$, tanto nas terras da Fazenda São Jeronimo como em localidades fora da área demarcada da Fazenda.

Em 1910, quando o Inspetor do SPI no Paraná o capitão Jose Ozório visitou as aldeias indígenas do Tibagi ele solicitou ao escrivão do Cartório de São Jerônimo, o Sr. João Henrique Elliot, que verificasse em seus livros se havia algum registro de doação das terras da fazenda aos índios pelo Barão de Antonina. Elliot encontrou o registro de doação e fez uma cópia a pedido do capitão José Ozório que a levou para Curitiba. Pelo registro, o inspetor tomou conhecimento que a fazenda doada pelo Barão de Antonina ao governo do Império era de seis léguas quadradas, equivalente 176.400 hectares (Anexo 1). 


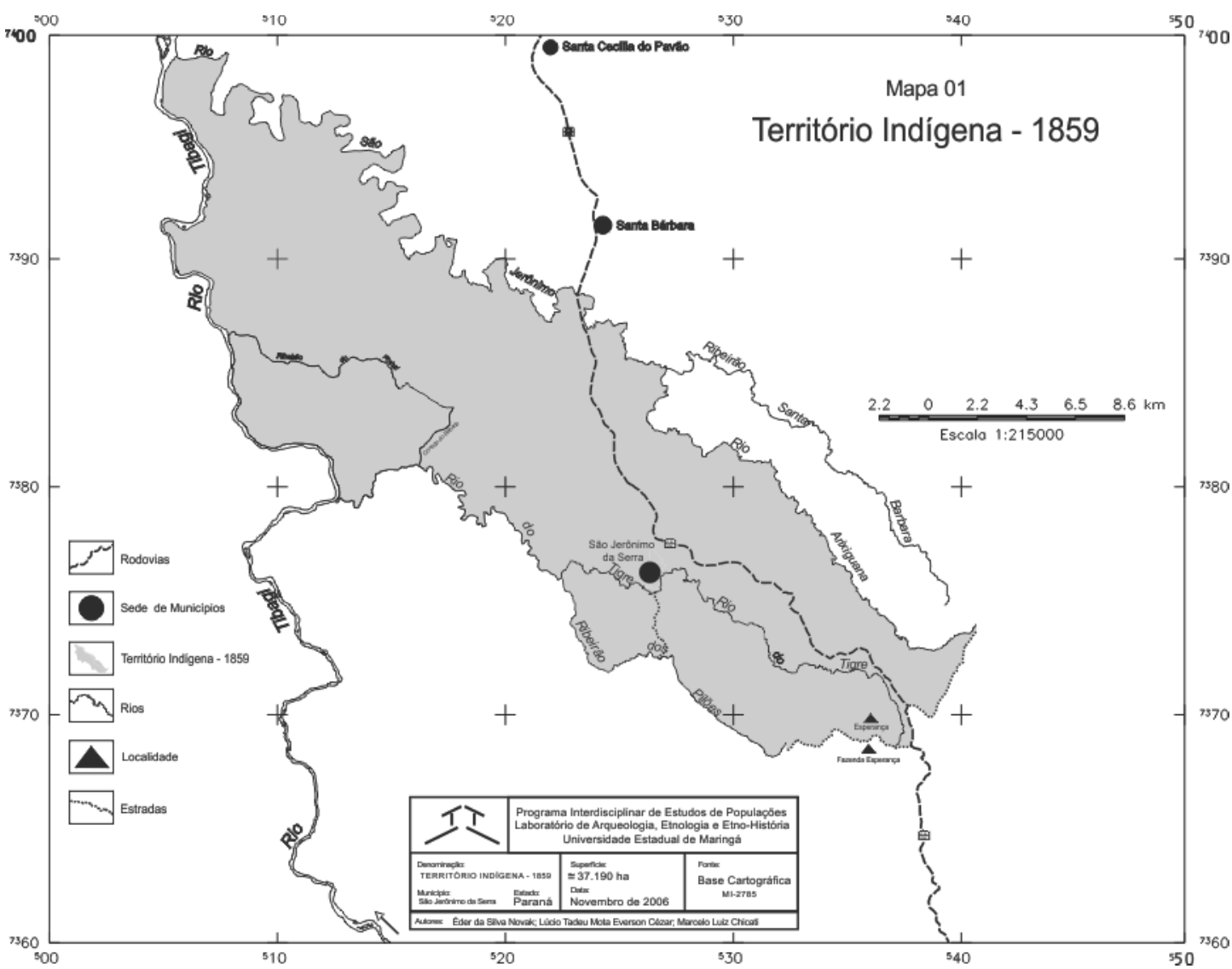

Figura 3. Território indígena da Fazenda São Jeronimo em 1859. Fonte. Os autores

A povoação indígena de São Jerônimo foi extinta e em seu lugar foi criado o município com o mesmo nome. A sede do município foi implantada no interior das terras Kaingang no local onde o governo do Império construiu a sede da Colônia Indígena em 1859. Como vimos acima, durane todas as décadas de 1910 a 1940 houve um tenso debate em torno da extinção da povoação indígena e sua transformação em município o que culminou em com o acordo de 1949. Mas antes da confirmação desse acordo o governo federal já tinha sinalizado que poderia haver a cessão de partes desses territórios para o governo do Paraná. É o que autoriza o Decreto Lei n 7.692, de 30 de junho de 1945, assinado pelo presidente Getúlio Vargas. (Anexo 2). 
Sinalizado em 1945 por Getúlio Vargas o total esbulho dos territórios indígenas de São Jerônimo deveria se concretizar com o "Termo de acordo" firmado entre a União e o Governo do Paraná em maio de 1949. Reunidos o Ministro da Agricultura e o governador do Paraná, o Sr. Moises Lupion, na sede do governo federal no Rio de Janeiro em 12 de maio de 1949, consideraram que as terras devolutas reservadas pelo referido Estado, em diversas épocas, para o estabelecimento de tribos ou agrupamentos indígenas, se encontravam em uma situação irregular. Isto considerado acordaram sobre a necessidade de reestruturá-las, para que elas pudessem ser conservadas. As áreas a serem reestruturadas deveriam ser aquelas que tinham sido definidas nos Decretos estaduais do início do século, a saber: Apucarana, Queimadas, Ivaí, Faxinal, Rio das Cobras e Mangueirinha. E a reestruturação deveria obedecer aos seguintes critérios conforme a cláusula terceira do termo:

(...) tendo em vista a população indígena atualmente existente em cada um dêsses Postos e adotando-se como critério básico para as respectivas extensões a área de 100 (cem) hectáres por família indígena de 5 (cinco) pessoas e mais 500 (quinhentos) hectáres para localização do Pôsto Indígena e suas dependências, será feita pelo Estado do Paraná a cessão definitiva, para plena propriedade tribal, das seguintes áreas compreendidas nos limites das atuais reservas: 6.300 (seis mil e trezentos) hectares na região de Apucarana; 1.700 (mil e setecentos) hectáres na região de Queimadas; 7.200 (sete mil e duzentos) hectáres na região de Ivaí, 2.000 (dois mil) hectáres na região de Faxinal; 3.870 (três mil oitocentos e setenta) hectáres na região do Rio das Cobras e 2.560 (dois mil quinhentos e sessenta) hectáres na região de Mangueirinha. (Cf. Termo de acordo entre o Governo da União e o Governo do Estado do Paraná, visando a regularização das terras destinadas aos índios no território daquele Estado e a prestação de maior assistência aos mesmos silvícolas. Publicado no Diário Oficial Federal n. 114 de 18 de maio de 1949).

As cláusulas seguintes do acordo ainda previa a imediata demarcação das terras, retirada de moradores não indígenas dessas novas áreas, construção de casas para as famílias indígenas, etc. E sobre os territórios da povoação indígena de São Jerônimo nenhuma menção. Estava implícito que eles deveriam se mudar para a área demarcada de 6.300 hectares da região do Apucarana.

Apesar do espolio de parte de seus territórios acordado entre o governo da União e do Estado do Paraná, é importante ressaltar que os indígenas souberam fazer frente a essa política de expropriação de seus territórios e não abriram mão de seus Emás na margem direita do rio Tibagi. Se as Terras Indígenas de São Jerônimo e Barão de Antonina existem hoje foi porque houve a resistência ao processo de expropriação em 1949. O papel dos agentes do SPI nesse episódio ainda está para ser desvendado e, com certeza, a documentação desse órgão existente no Museu do Índio pode trazer novas revelações sobre o papel da agência e dos próprios indígenas.

\begin{tabular}{llllll} 
N & Terras Indígenas & Etnias & Município(s) & Situação fundiária & Área (Ha) \\
\hline 1 & Barão de Antonina & Kaingang & São Jerônimo da Serra & Registrada no SPU (1977) e no CRI (1992) & 3.750 ha \\
\hline 2 & São Jerônimo & Kaingang Guarani Xetá & São Jerônimo da Serra & Registrada no SPU (1977) e no CRI (1992) & 1.339 ha
\end{tabular}




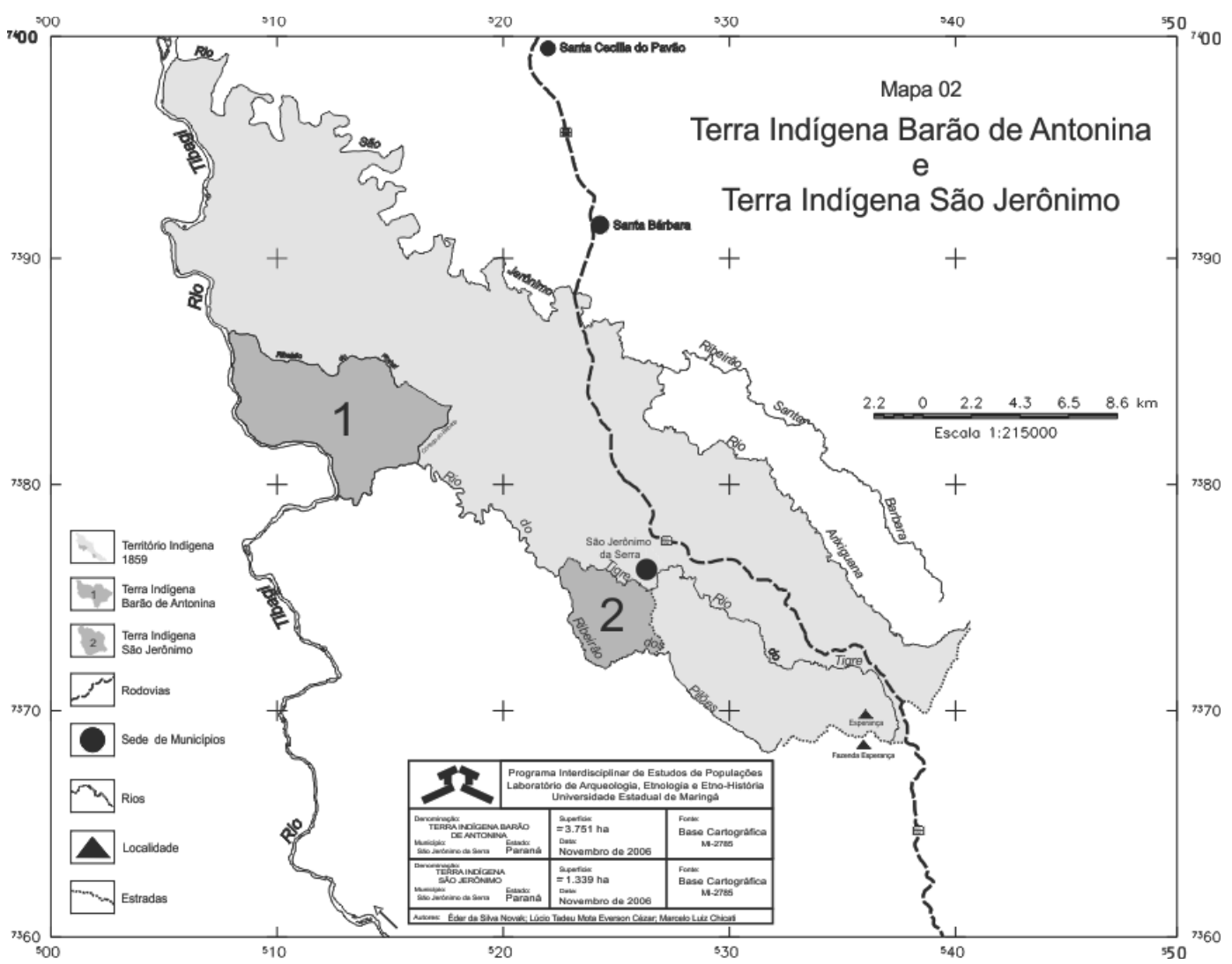

Figura 4. As atuais Terras Indígenas de São Jeronimo e Barão de Antonina. Fonte. Os autore

\section{Os territórios indígenas na Serra da Apucarana}

Conforme vimos anteriormente no início do século XX o governo do estado do Paraná demarcou uma área dos territórios Kaingang na margem esquerda do rio Tibagi. Esta demarcação ocorreu em 5 de julho de 1900, através do Decreto $n^{\circ} 6$, durante o governo de Francisco Xavier da Silva.

O Governador do Estado do Paraná, considerando que os indigenas da tribu dos Coroados, dos extinctos aldeamentos de S. Jeronymo e S. Pedro de Alcantara, no municipio de Tibagy, abandonaram a vida nomade, e que é de equidade que thes conceda um trato de terras em que se estabeleçam e se dediquem à lavoura, à que, aliás, estão affeitos, e onde possam ir se agremiando outra tribus, que vivem na zona sita entre os rios Paranapanema, Tibagy e Ivahy: Considerando que as terras d'aquela zona estão passando ao domínio particular, já por meio de posses feitas em tempo util, que estão sendo legitimadas, já por compra ao Estado, e que, em consequência d'isso, os indígenas serão pouco a pouco d'alli expelidos, si não lhes ficar reservada uma determinada área das ditas terras, para o seu estabelecimento, e as cultivarem, decreta: 
Art. unico. Ficam reservadas, para estabelecimento de colonias indígenas, as terras devolutas sitas entre os rios Tibagy, Apucarana, Apucaraninha e a serra do Apucarana, no município de Tibagy.

A análise deste decreto permite deduzir que o governo do Paraná procurou agrupar os diversos grupos indígenas em uma área. Os representantes políticos do estado afirmavam que as populações indígenas haviam abandonado a vida nômade e que após anos de vivência nos aldeamentos se dedicariam à lavoura e, por este motivo, era necessário um "trato de terras". A intenção do governo era agrupar os indígenas em uma determinada área e liberar outras tantas para negociar com as colonizadoras e particulares.

O texto do Decreto revela, ainda, que os índios estavam por toda região, nas terras compreendidas entre os rios Paranapanema, Tibagi e Ivaí, e demonstra a existência de diversos grupos indígenas e seu caráter itinerante de manejo de territórios com constantes deslocamentos, mas sempre mantendo seus territórios tradicionais.

Ainda sobre esta demarcação, no relatório da Secretaria dos Negócios de Obras Públicas e Colonização apresentada ao governador Francisco Xavier da Silva em 1901, o governo justificava a demarcação de terras aos índios "No intuito de dar aos selvicolas um paradeiro certo para se localisarem sem receio de serem desalojados, e onde possam constituir as suas aldeias e curar dos trabalhos agrícolas"(Arquivo Público do Paraná. Curitiba. Relatório da Secretaria dos Negócios de Obras Públicas e Colonização apresentado ao governador, Sr. Francisco Xavier da Silva, em 1901).

O governo concebia que os indígenas se adaptariam ao trabalho da lavoura. Isso era o que o governo imaginava, porque os indígenas tinham outros planos: queriam acessar os bens da sociedade envolvente sem deixar de viver conforme seus costumes, e os trabalhos agrícolas nos moldes dos brancos não estavam nos seus planos. Quem fazia as grandes roças de milho e feijão nas Colônias Indígenas eram os escravos do Império cedidos para trabalhar e servir aos administradores dessas Colônias.

Um dado importante que o Decreto $\mathrm{n}^{\circ} .6$ ainda deixa transparecer é o fato de afirmar que esta área reservada era para o estabelecimento dos indígenas da tribu dos Coroados. Na verdade, Coroados era outra denominação empregada para identificar os índios Kaingang naquela época. Dessa forma, os Guarani e os Kayowá que ainda viviam nas imediações de São Pedro de Alcântara não se deslocaram para esta área reservada, devido à histórica disputa de territórios com os Kaingang.

Neste jogo de interesses a área reservada aos índios ficou estabelecida "nas terras devolutas sitas entre os rios Tibagy, Apucarana, Apucaraninha e a serra do Apucarana, no município de Tibagy". Pelo fato de os limites terem uma certa precisão foi possível calcular o seu tamanho a partir do georreferenciamento. De acordo com os limites estabelecidos pelo Decreto, ela teria mais de sessenta e oito mil e quinhentos hectares (68.536 ha). 


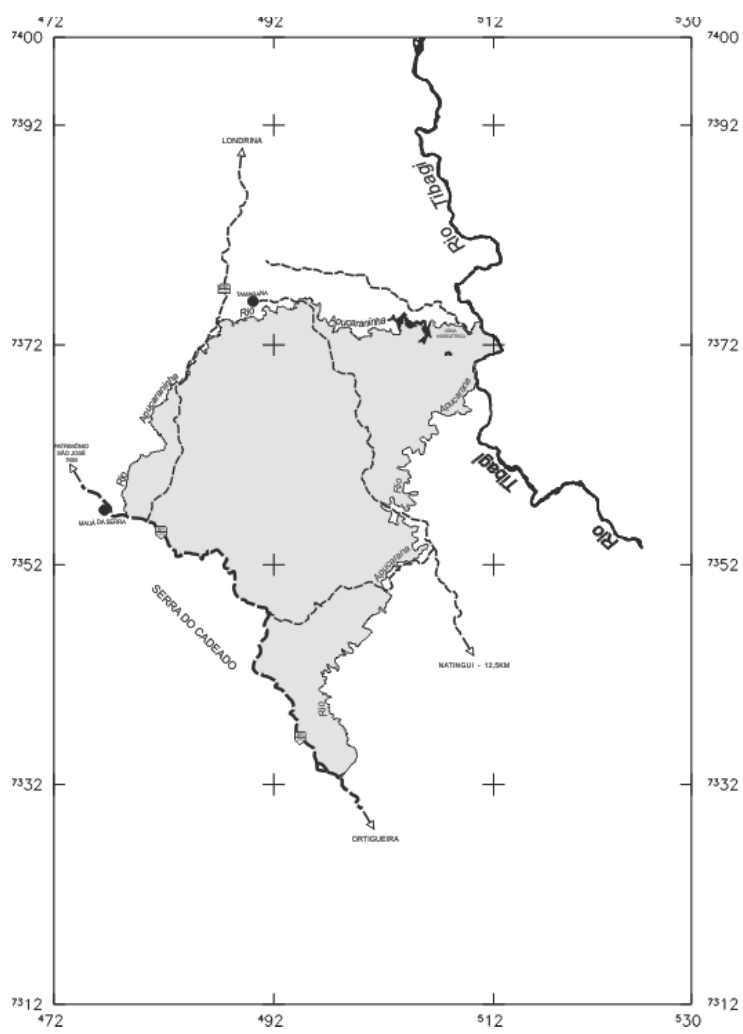

\section{Mapa 03 \\ Território Indígena Apucaraninha}

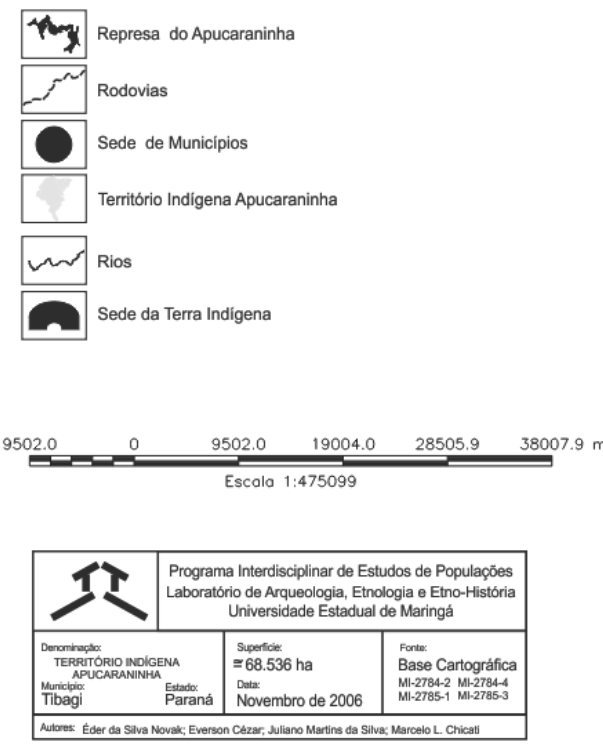

Figura 5. Território indígena do Apucaraninha em 1900 Fonte. Os autores

Esta área não era a única ocupada pelos Kaingang na margem esquerda do rio Tibagi. Havia muitos grupos espalhados ao longo do rio Tibagi que poderiam até se apresentar na sede da área demarcada, para obterem alguma vantagem ou benefícios concedidos, mas nem todos ali permaneciam, deslocavam-se para suas moradias em outras localidades. Efetivamente, há indícios de diversas aldeias fora da área demarcada tanto ao norte do rio Apucaraninha como em direção ao Sul na região do Rio Preto até as proximidades dos aldeamentos da Serra do Cadeado nos divisores das águas dos rios Tibagi e Ivaí.

O território indígena do Apucarana que em 1900 poderia ter até 68.536 ha, com o acordo de 1949 foi reduzido para 6.300 ha. Vejamos os termos do acordo para Apucarana: “(...)será feita pelo Estado do Paraná a cessão definitiva, para plena propriedade tribal, das seguintes áreas compreendidas nos limites das atuais reservas: 6.300 (seis mil e 
trezentos) hectares na região de Apucarana" (Cf. Termo de acordo entre o Governo da União e o Governo do Estado do Paraná, visando a regularização das terras destinadas aos índios no território daquele Estado e a prestação de maior assistência aos mesmos silvícolas. Publicado no Diário Oficial Federal n. 114 de 18 de maio de 1949).

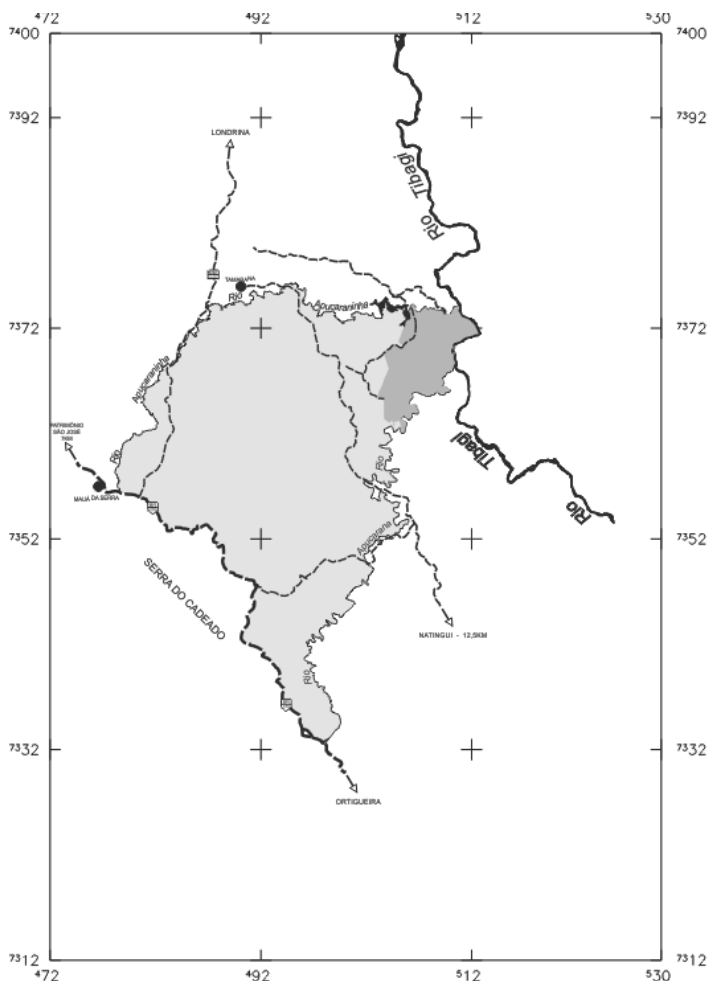

\section{Mapa 04 \\ Terra Indígena Apucaraninha}
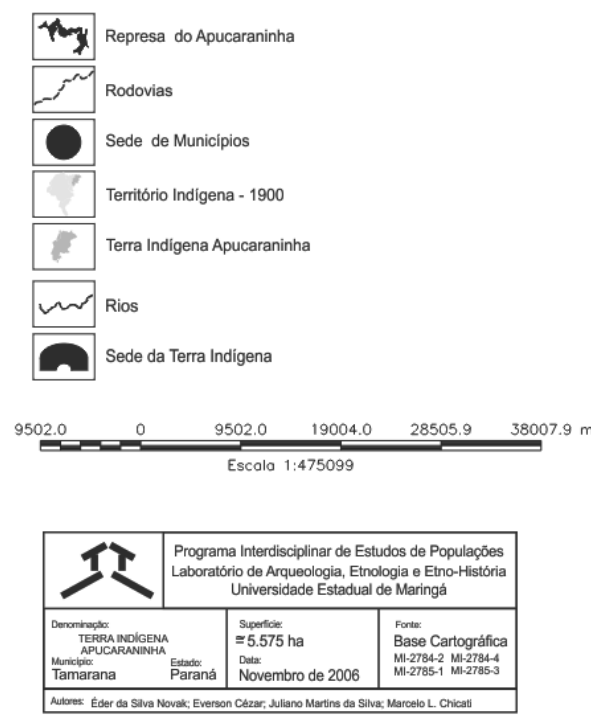

Figura 6.. Atual Terra Indígena Apucaraninha e o território em 1900. Fonte. Os autores

O que era 68.536 há em 1900 foi reduzido para 6.300 há em 1949, e depois para 5.575. Mas os Kaingang do Apucaraninha não deixaram de lutar pelos seus territórios e hoje buscam retomar uma área de 725 ha em posse da empresa Nutrimental Agropecuária Ltda.

\begin{tabular}{lllll} 
N & Terras Indígenas & Etnias & Município(s) & Situação fundiária \\
\hline 3 & Apucarana & Kaingang & Tamarana & $\begin{array}{l}\text { Registrada. Situação atual: os Kaingang } \\
\text { reivindicam uma área de } 725 \text { ha em posse da } \\
\text { empresa Nutrimental Agropecuária Ltda. }\end{array}$
\end{tabular}




\section{Terra indígena de Mococa}

Mais ao Sul da Terra Indígena Apucaraninha, subindo o rio Tibagi pela margem esquerda vamos encontrar a Terra Indígena Mococa. A história dela é diferente das narradas até agora. Consta na documentação oficial do estado que em 1903 foi aprovada uma nova medição de terras a um grupo Kaingang no município de Tibagi. Dessa vez a pedido do Capitão Timóteo, cacique de um grupo Kaingang que habitava aquelas terras. O relatório da Secretaria do Estado dos Negócios de Obras Públicas e Colonização, no final de 1903, afirmava:

(...) tendo o Capitão Timóteo, chefe da tribu dos coroados e a mais 40 individuos da mesma tribu, obtido por uso fruto nos termos do Art. ${ }^{\circ} 75$ do Decreto $\mathrm{n}^{\circ} 1318$ de 30 de janeiro de 1854, uma área de terras contendo oito milhões trezentos e setenta e sete mil e oitocentos e oitenta e nove metros quadrados ou ( $837 \mathrm{~h}, 78 \mathrm{a}, 89 \mathrm{c}$ hectares) no município de "Tibagy" se acha o mesmo Capitão Timoteo, chefe da tribu dos Coroados e mais 40 da mesmatribu,pelo presente título, investido do direito de dominio direto sobre as terras contidas na referida área, salvo direito de terceiros e respeitados as prescrições das leis e regulamentos em vigor.( Arquivo Público do Paraná. Curitiba. Relatório da Secretaria do Estado dos Negócios de Obras Públicas e Colonização, 1903).

O governador em exercício, Manoel de Alencar Guimarães, e o secretário Francisco Gutierrez Beltrão, ao analisarem o pedido do Capitão Timóteo e verificarem a documentação anterior, que concedia as terras a este grupo indígena em Tibagi, aprovaram a medição das referidas terras, registrando o título das mesmas à folha 225 do livro terceiro de 1903.

Titulo de dominio direto das terras obtidas por uso fruto pelo Capitão Timoteo, chefe da tribu dos coroados situadas no municipio de Tibagí, cujo processo fica arquivado sob $\mathrm{n}^{\circ}$..... da seção do Arquivo.

O Diretor, Luiz F. França.

Este titulo fica registrado á folha 225 do livro terceiro. O encarregado do registro, Augusto Cezar Espínola.

Sentença em virtude da qual foi expedido o presente titulo;

Visto e examinados os autos. E considerando que a lei $n^{\circ} 68$ de 20 de dezembro de 1892 artigo 19 determina, como já o faziam a lei n 601 de 18 de setembro de 1850, e o seu regulamento, que o Governo "reservará" as terras devolutas que forem julgadas necessárias para a fundação de colonias, por maioria de razão tem o Governo da garantir aos indigenas a posse das terras em que tem seus aldeiamentos; Considerando que a aludida tribu de coroados está ocupando com cultura efetiva e morada habitual as terras ora medidas e demarcadas as quaes lhe são necessarias para o desenvolvimento da indústria agricola a que se dedicam; aprova a presente medição para efeito de ficarem as terras sobre ela versa destinadas ao uso fruto da mencionada tribu, nos termos do artigo 75 do Decreto $\mathrm{n}^{\circ} 1318$ de 30 de janeiro de 1854.

Mas a versão dos Kaingang da Terra Indígena Mococa não é a mesma descrita acima nos documentos de 


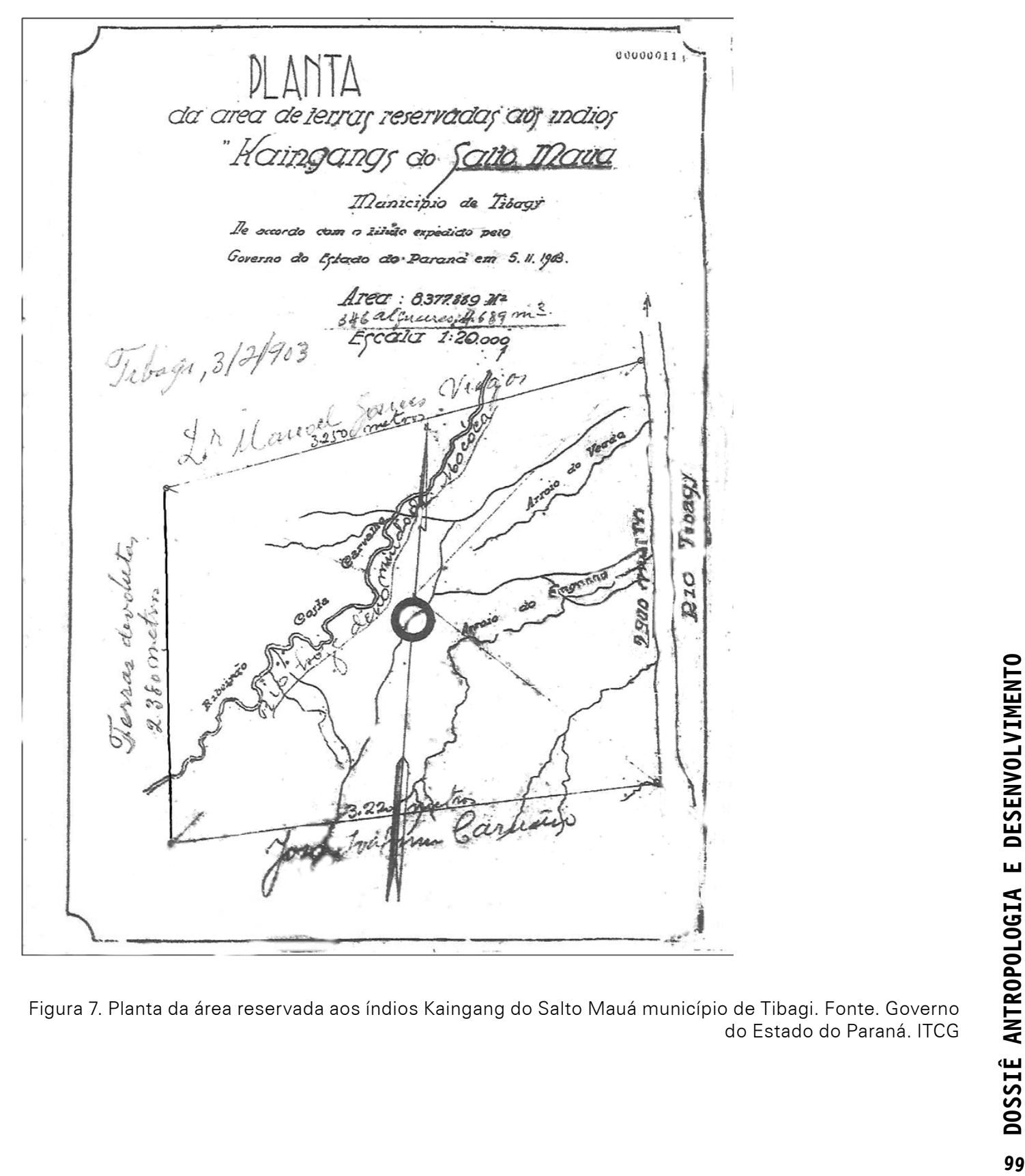


titulação fornecido pela burocracia do Estado. O Sr. Augusto Merenciano Kogoia, neto do velho capitão Timotheo, contou que seu avô comprou do governo aquelas terras.

Meu avô (Capitão Velho Timótheo = Timotheo Gojé) ${ }^{14}$ morava lá no Laranjinha. Ele foi procurar uma morada para morar longe. Mas naqueles tempos não tinha estrada, só mato. Então ele veio só pelo Rio Tibagi. Ele veio com o poder da água. Vieram 25 famílias do Laranjinha. Tinham doze canoas pra ele carregar família e carregar coisa pra comer também. Meu avô tinha quatro filhas e tinha quatro homens. Trouxe todos por dentro da água pelo Rio Tibagi. Daí eles fizeram os ranchos para morar, aqui pra baixo. Plantaram milho, arroz, feijão. Foram olhar os peixes no rio. E então eles foram lá para Curitiba, pedir um lugar bom para morar, pedir terreno. Aí o governo falou: ‘O que vocês vieram pedir para mim?' 'Eu vim pedir terra, um chão para morar.' E o governo disse que não dava, mas podia vender. Os Kaingang falaram que queriam quinhentos alqueires de terra e o Governo de Curitiba disse que vendia por 100 mil réis"15

Conforme a narrativa do Sr. Augusto, os Kaingang comandados pelo seu avô tiveram que pagar $100 \$ 000$ (cem mil réis) pelas terras. Como não tinham o dinheiro, foram trabalhar numa empreitada de derrubada de mato para o governo e com isso quitaram a dívida.

Dessa forma, o cacique Timotheo conseguiu do governo estadual a titulação de uma parcela de 837 hectares (349 alqueires) de terras na margem esquerda do Rio Tibagi, logo abaixo do Salto Mauá, em 5 de novembro de 1903. Mas ele manejava territórios muito mais amplos, pois, quando da visita da expedição da Inspetoria Regional do SPILTN em seu emã em dezembro de 1910, ele não se encontrava, estava caçando distante uns $12 \mathrm{~km}$ de seu emã. Tanto que o capitão Ozório teve de esperar sua volta para distribuir os brindes, fazer o recenseamento e conversar sobre outras questões e informações relativas ao aldeamento.

Na história da migração de seus antepassados, do Rio Laranjinha para o Rio Tibagi, o Sr. Augusto Kogoia descreve os diversos locais onde seu avô e familiares faziam seus waré (acampamentos de caça provisórios) tinham suas roças, seus paris (armadilhas de pesca) e seus cemitérios. Percorriam a Krin-yú-rãn-rãn (Serra Grande), subiam o Rio Tibagi e adentravam seus afluentes como ribeirão Mococa, Rio Dó Kanébang (Rio Barra Grande), e muitos outros.

Este contexto apresenta uma situação que ilustra o que acontecia na maioria das outras áreas demarcadas para os índios nesse início de século: apesar do emã estar situado dentro de limites demarcados, os grupos familiares se deslocavam para fora desses limites manejando áreas territoriais muito mais extensas, conforme suas necessidades materiais, socioculturais e religiosas.

A Terra Indígena Mococa tem hoje 859 hectares, quase as mesmas dimensões da área comprada pelo cacique Timóteo em 1903 de 837 ha, talvez a pequena diferença de 22 hectares seja devido à precisão das medições. 0 que nos parece interessante é que o governo do Paraná não fez menção dessa área no acordo de 1949, será que aqui por ter sido uma área comprada foi respeitado o direito de propriedade dos indígenas? 


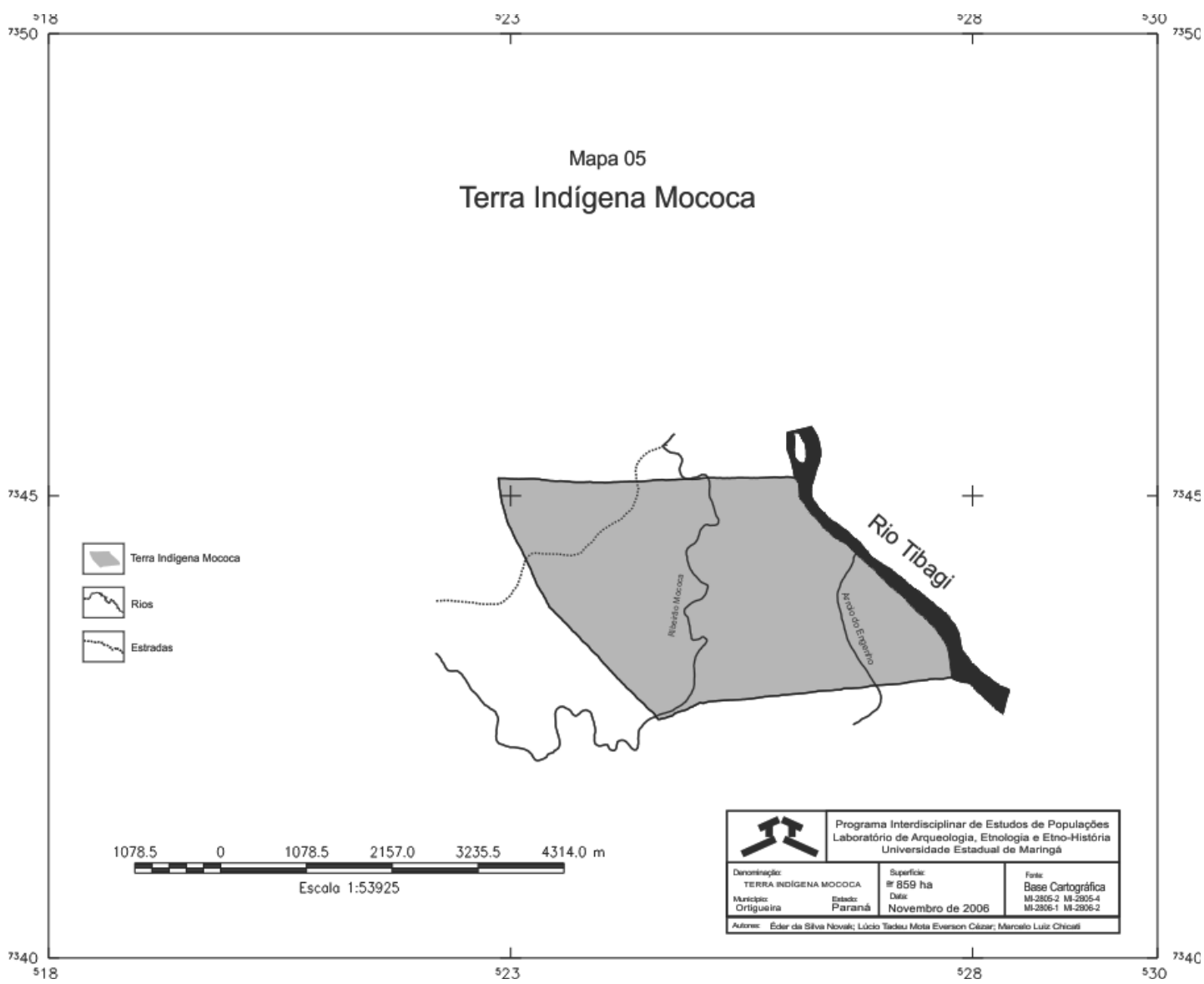

Figura 8. Atual Terra Indígena Mococa. Fonte. Os autores

\begin{tabular}{llllll} 
N & Terras Indígenas & Etnias & Município(s) & Situação fundiária & Área (Ha) \\
\hline 4 & Mococa & Kaingang & Ortigueira & Registrada no SPU (1996)
\end{tabular}




\section{Os territórios Kaingang da Serra do Cadeado nos divisores dos rios Tibagi e Ivaí.}

Ainda na margem esquerda do rio Tibagi, uma nova área foi reservada aos índios Kaingang que habitavam as serras divisoras dos rios Tibagi e Ivaí. A situação dos Kaingang nessa região do médio Rio Tibagi e Serra do Cadeado apresentava duas circunstâncias diferenciadas. Enquanto o cacique Timotheo tinha uma terra demarcada, mas circulava por territórios maiores, os Kaingang liderados pelos caciques Ferreira e Alfredo Veigmon não tinham nenhuma demarcação de seus territórios e estavam sendo espremidos pela frente de ocupação que chegava às encostas do terceiro planalto.

Essa frente de ocupação, iniciada no final do século XIX e acelerada no início do XX, era constituída de diferentes contingentes populacionais. Havia os homens pobres e livres que viviam nas franjas das grandes fazendas de gado dos Campos Gerais que já faziam esse movimento de deslocamento para oeste em busca de terras "livres" desde o século XIX. Para a região também rumava os excedentes populacionais de outros Estados, como Minas Gerais, São Paulo e mesmo do chamado Norte Velho do Paraná que vislumbravam a possibilidade de conseguir uma parcela de terras para criar porcos no sistema safrista. Com informações e a proteção de autoridades da capital e das cidades próximas, políticos, grandes fazendeiros e apaniguados do governo local procuravam ampliar seus patrimônios açambarcando grandes extensões de terra, conseguindo concessões escandalosas em verdadeiros bendegó no dizer do cacique Ferreira. E, por fim, uma parcela menor, mas a mais perigosa, da população que chegava na vila de Queimadas era de foragidos da justiça que internavam-se naquelas serras sem outra intenção de fugir da justiça e continuar seus malfeitos. Eram esses indivíduos os recrutados pelos grandes grileiros para limpar as terras: seja dos nacionais pobres que tinham usucapião de seus terrenos, seja dos Kaingang que estavam nesses territórios.

Essa frente de ocupação heterogênea, mas determinada a conseguir propriedades de terras, ameaçava deixar os Kaingang sem seus territórios antes que o governo os demarcassem. Essa era a situação enfrentada pelos caciques Ferreira e o jovem Veigmon. E eles com certeza fizeram suas queixas ao representante do governo federal contra o esbulho dos seus territórios. O Relatório do capitão Ozório, inspetor do SPI no Paraná, que visitou as aldeias dos Caciques Ferreira e Alfredo Veigmon, chegou ao SPI no Rio de Janeiro no início de 1911. As autoridades federais tomaram conhecimento da situação da Serra do Cadeado e cinco anos depois, o governo do Estado do Paraná emitiu o Decreto 591 de 17 de agosto de 1915, demarcando as terras para os Kaingang da Serra do Cadeado:

O Presidente do Estado do Paraná tendo em vista garantir a propriedade da lavoura dos indios Caigangs estabelecidos nos toldos denominados Faxinalsinho, Palmital e Faxinal do Cambará, decreta:

Art. 1. ${ }^{\circ}$ Fica reservada para o estabelecimento dos indios Caigangs dos toldos denominados Faxinalsinho, Palmital e Faxinal do Cambará, no Municipio de Tibagy, salvo direito de terceiros, uma área de terras comprehendidas nos seguintes limites: Principiando na barra do rio do Rosario no rio Alonza, por este acima até a barra do arroio Bonito, por este acima até a primeira vertente acima da Pedra Branca, por esta vertente acima até a serra a procura de uma vertente que desagua ao lado esquerdo do arroio dos Poços, por este abaixo até o ribeirão das Formigas, e por este abaixo até o rio Barra Grande, por este acima até as cabeceiras, d'ahi pela divisa da fazenda da Apucarana até a cabeceira do rio Rosario e por este abaixo até a sua fóz onde começou. 
A ideia inicial do governo do Paraná de agrupar todos os indígenas do vale do Tibagi na área reservada entre os rios Apucarana e Apucaraninha também não ocorreu com os grupos da Serra do Cadeado, e ele teve que fazer uma nova demarcação em 1915. Pelo texto do Decreto ficou claro o objetivo do governo: agrupar os grupos indígenas de diferentes toldos na mesma área, no caso as aldeias de Faxinalzinho, Palmital e Faxinal do Cambará. $\mathrm{O}$ governo mantinha a ideia de reservar terras para os índios se dedicarem à lavoura e, além disso, ainda desenvolvia uma política contraditória, pois afirmava que poderiam existir propriedades de terceiros dentro da área reservada aos índios, possibilitando novos conflitos entre os grupos envolventes.

Conforme descrição detalhada dos limites esta área possuía aproximadamente 22.632 ha, conforme Mapa 06, sendo reservada a um grupo Kaingang no município de Tibagi.

Conforme o estipulado no acordo de 1949, ela teria 1.700 (mil e setecentos) hectares na região de Queimadas. Com certeza houve resistência e os indígenas conseguiram elevar os 1.700 hectares iniciais para os 3.078 atuais. Uma pesquisa na documentação do SPI e do estado do Paraná certamente mostrará os detalhes da não aceitação do estipulado no "acordo" de 1949 e as estratégias dos indígenas para aumento do da área.

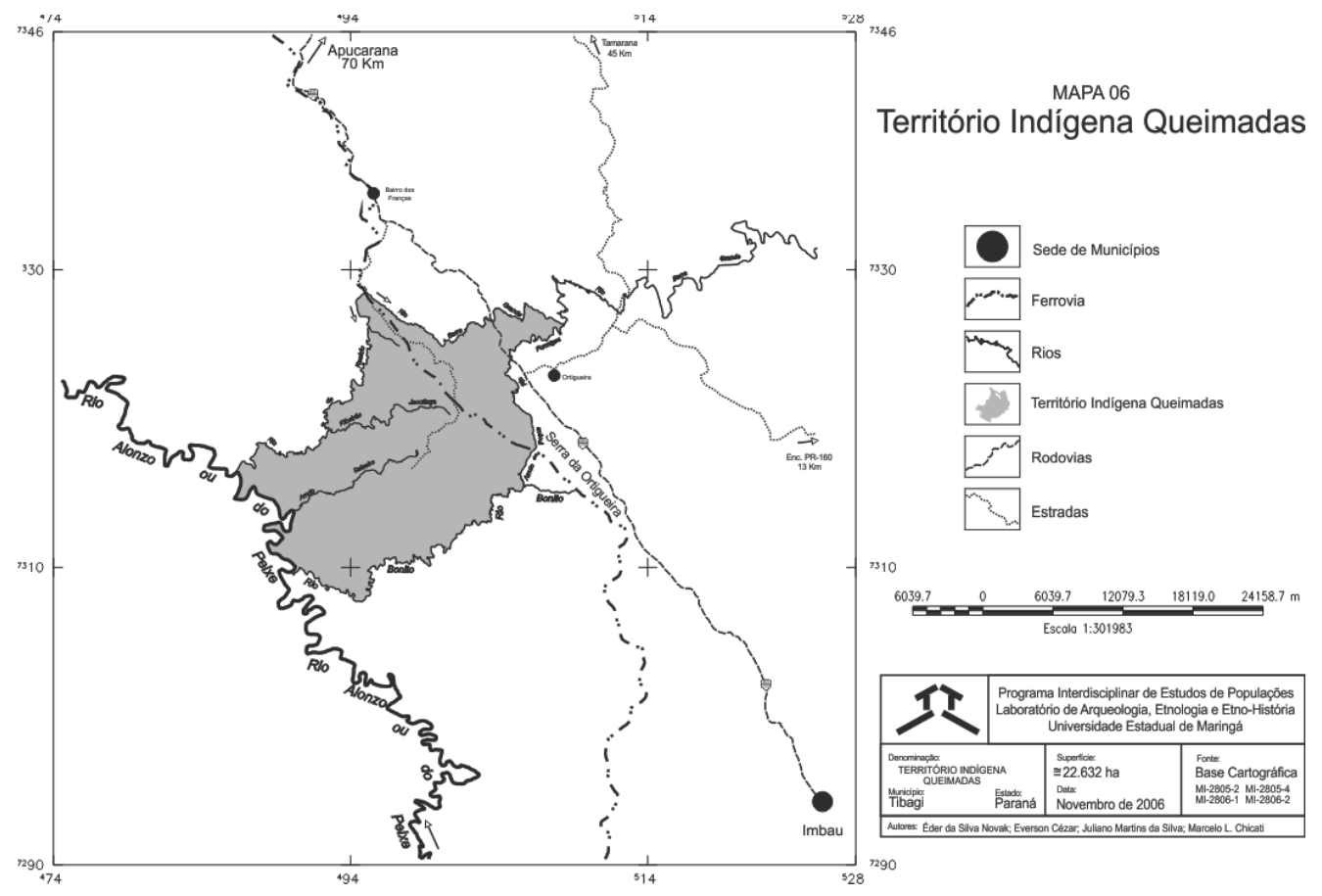

Figura 9. Territórios Kaingang na Serra do Cadeado em 1915. Fonte. Os autores 


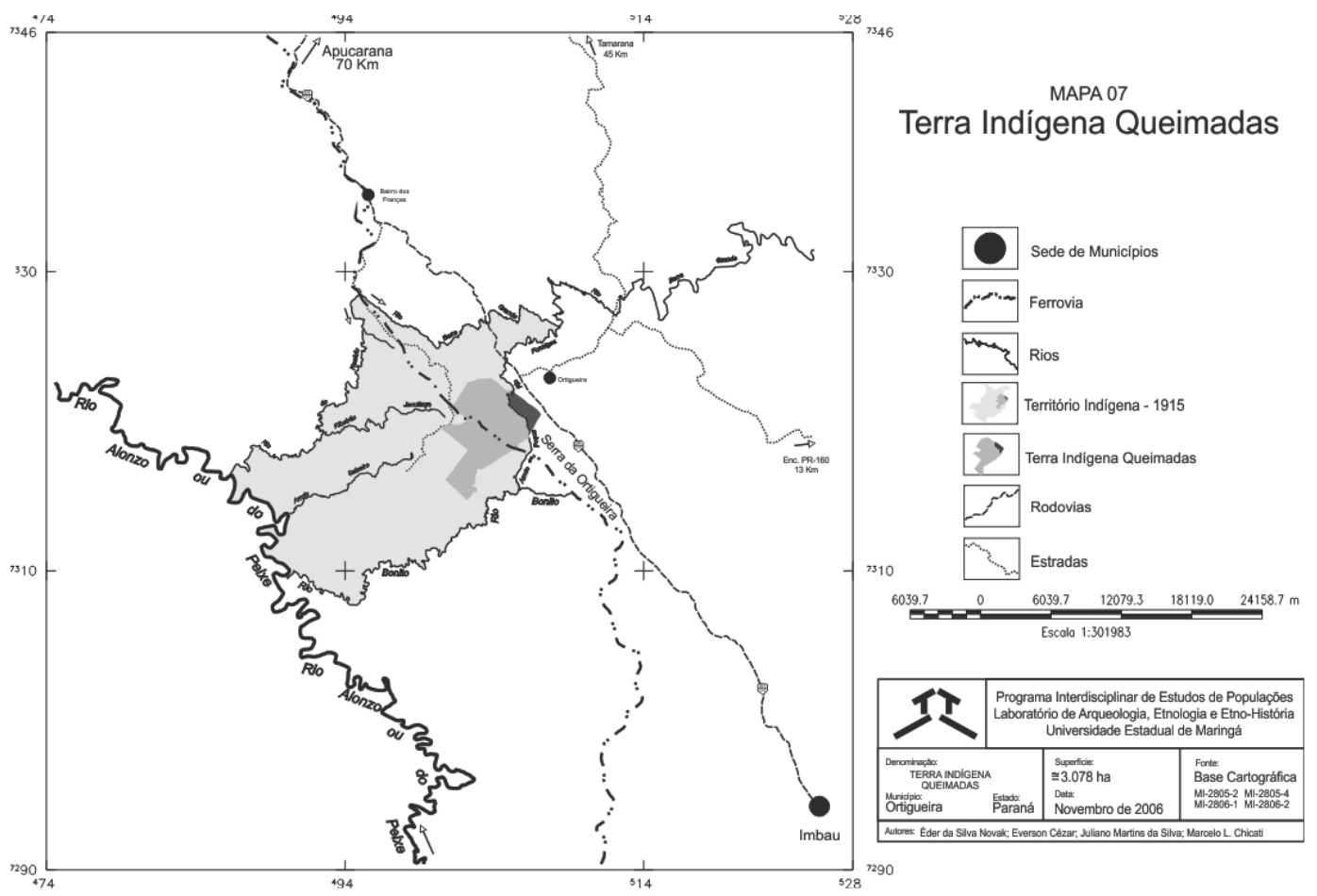

Figura 10. Atual Terra Indígena Queimadas. Fonte. Os autores

\begin{tabular}{lllll} 
N & Terras Indígenas & Etnias & Município(s) & Situação fundiária \\
\hline 5 & Queimadas & Kaingang & Ortigueira & Registrada no CRI (1996) e no SPU (1998)
\end{tabular}

\section{CONSIDERAÇÕES FINAIS}

O vale do rio Tibagi foi ocupado por diversos grupos indígenas. Primeiro por caçadores coletores desde a 9.000 anos antes do presente. Depois pelas populações de agricultores e ceramistas, ancestrais dos atuais Kaingang e Guarani, que chegaram à região por volta de 2.000 anos antes do presente. 
Por ocasião da chegada dos primeiros europeus no início do século XVI o vale do Tibagi estava todo ocupado pelos falantes Guarani nas proximidades do rio e seus afluentes maiores e pelos falantes Jê nas Serras e encostas mais distantes dos cursos d'água. E desde então, verificamos que essas populações sempre estiveram atuantes em defesa de seus territórios e modos de vida, sejam através de políticas de alianças, acordos, reivindicações e solicitações pacíficas, sejam através da guerra e da dura resistência frente aos invasores.

Em cada conjuntura, enquanto sujeitos históricos, desenvolveram políticas e estratégias para lidar com seus vizinhos e com os poderes estabelecidos. Isto não significa omitir a expropriação de seus territórios, mas entender que frente à política indigenista traçada pelos conquistadores, também se articulou uma política indígena que foi responsável pela manutenção de parte de seus territórios, evidenciada pela presença de mais de 3.500 indígenas vivendo atualmente em cinco Terras Indígenas ao longo do rio Tibagi.

O episódio do acordo de 1949 que espoliou grandes parcelas de seus territórios não representou o último capítulo de expropriação de terras e riquezas dos grupos indígenas do rio Tibagi. Ela continuou na segunda metade do século XX com as atividades de extração de madeira, mineração de diamantes e retirada de areia, construção de usinas hidrelétricas e o intenso agronegócio do entorno, contribuindo para a poluição das águas e o empobrecimento da diversidade ambiental do interior das áreas demarcadas. Da mesma forma, continuou o protagonismo indígena com ações de expulsão de invasores de suas terras como foi o caso da retirada de posseiros da área do Cedro na T. I Barão de Antonina nos anos de 1990, e a retomada de uma área vizinha na T.l Apucaraninha em 2009, ou de negociações intensas visando compensações financeiras e ambientais realizadas com Cias de Energia e concessionárias de estradas de ferro na primeira década do século XXI. Estas ações reafirmam os indígenas do vale do Tibagi enquanto sujeitos históricos do seu tempo.

Eder da Silva Novak é doutorando em História pela Universidade Federal da Grande Dourados (UFGD) e professor colaborador do departamento de História da Universidade Estadual de Maringá (UEM).

Lucio Tadeu Mota é doutor em História pela Universidade Estadual de São Paulo (UNESP/Assis) e professor no Programa de Pós-Graduação em História da Universidade Estadual de Maringá (UEM) e da 


\section{NOTAS}

1 Sobre a história dos índios no vale do rio Tibagi ver: Cavalcanti 1924; Mota 1997; Mota; Bonnici 2008; Mota 2000a; Mota 2000b; Tommasino 1995

2 Há uma ampla e complexa literatura sobre a questão da territorialidade indígena, não cabe aqui a reprodução dessa discussão, mas indicamos alguns textos que serviram de baliza para a reflexão sobre o assunto. Cunha 1987; Seeger; Viveiros de Castro 1978 ; Ramos 1986; Little 2002. Especificamente sobre os Kaingang no rio Tibagi ver Tommasino 2000.

3 Conferir o Artigo 64 da Constituição Federal de 1891. Existe uma extensa bibliografia sobre a questão da terra no Império e na República que não cabe aqui listar. Especificamente sobre a questão da terra e os índios, ver Paula 1944

4 Sobre essa questão ver: Chmyz 1976; Chmyz et al. 2008; Noelli 2000; Parellada 2006.

5 Para mais detalhes sobre esses decretos ver Coleção de leis do Império, Ver também Primerio 1942, que trata no capítulo III, na perspectiva dos religiosos, especificamente sobre a missão oficial dos capuchinhos no Brasil no Império. Sobre as políticas do Império para os indígenas ver: Mota 1998.

6 João da Silva Machado - Barão de Antonina - nasceu em Taquari, no Rio Grande do Sul, em 17/06/1872. Aos 18 anos de idade fez sua primeira viagem para Sorocaba tangendo tropas para comercializar, fixou-se nas margens da estrada para o sul nos campos da Faxina, nas proximidades de Itararé, em São Paulo. A partir de 1820 passou a figurar na política paulista enquanto continuava suas atividades comerciais de vender animais em Sorocaba, a empreitar a construção de estradas na província e no início dos anos de 1840 iniciou as explorações e apropriação de imensos territórios indígenas no Paraná e Mato Grosso. A partir de 1853, com a independência da província paranaense, ele se tornou senador pela mesma e passou a viver na capital paulista, onde morreu em 28 de março de 1875. Foi um dos homens mais poderosos e influentes do Império. Para maiores detalhes da sua biografia, ver Brotero s/d; Almeida 1947; E especificamente sobre suas explorações no Paraná e Mato Grosso, ver o artigo de Wissenbach 1995.

7 Tekoha é a denominação Guarani para seus locais de moradia. "El tekoha es "el lugar en que vivimos según nuestras costumbres", es la comunidad semi-autónoma de los Paí. Su tamaño puede variar en superficie (...) en la cantidad de familias (de 8 a 120 en los casos extremos), pero estructura e función se mantiene igual". (Meliá; Grunberg; Grunberg 1976: 218).

8 Para mais detalhes sobre as Colônias Indígenas ver Mota 2000. Sobre a vida de Frei Timotheo de Castelnovo ver Orleans 1957; Franco 1936; Frigo 1995.

9 Em 1915, o Governo do Paraná ainda regulamentou as terras dos índios Kaingang na Serra do Cadeado. Decreto 591. (17/08/1915) Estado do Paraná - Coleção de Decretos e Regulamentos de 1915. Fixa os limites das terras dos Kaingang estabelecidos nos toldos de Faxinalsinho, Palmital e Faxinal do Cambara.

10 Arquivo Público do Paraná. Curitiba. Relatório da Secretaria de Estado dos Negócios de Obras Públicas e Colonização apresentado ao Presidente do Estado, Dr. Fernando Xavier da Silva, em 31 de dezembro de 1911, pelo secretário Bacharel Claudino Rogoberto Ferreira dos Santos. Enquanto o Decreto n. 8.941 fundava a povoação indígena de São Jerônimo, outro Decreto, n. 542, também em 1911, reservava terras para a fundação de um núcleo colonial, inclusive, em locais próximos um do outro, também com a participação do SPI.

11 Para mais detalhes sobre os territórios indígenas no vale do rio Tibagi no início do século XX ver Mota 2014.

12 Existe no Museu do Índio no Rio de Janeiro uma massa de documental oficial do SPILTN, que foi gerada por Inspetorias Regionais. Referente a $7^{a}$ Inspetoria Regional do Paraná, no período de 1910 a 1967 período de duração do SPÍ, há quarenta e dois (42) filmes, ultrapassando cem mil (100.000) fotogramas. Especificamente sobre os territórios indígenas no vale do Rio Tibagi, há nove (9) filmes com 14.278 fotogramas. Foram microfilmados todos os tipos de documentos: desde relatórios impressos com espaços para preenchimentos de dados, relatórios, ofícios, memorandos, ordens de serviço, correspondências datilografadas, até relatórios, cartas e solicitações manuscritas. Também há fotografias, croquis de áreas de terras e plantas de edificações. Essa documentação é de vital importância para a pesquisa histórica sobre as populações indígenas no Paraná nesse período. 
13 A palavra emá significa conforme o Dicionário de Val Floriana: “Jamá: Minha terra, meu bairro, minha morada. Terra, bairro, etc. se traduzem com emá, amá".

14 "O nome indígena Gojé significa madeira coberta de cipó. O nome português Thimotheo demonstra a ligação do mesmo com o frei capuchinho, Timótheo Castellnuevo, que deve ter batizado Gojé e lhe dado seu nome." Essa nota pertence ao texto de Casão 2007.

15 As narrativas do Sr. Augusto Merenciano Kogoia foram feitas para Carolina Casão, Kimiye Tommasino e Lúcio Tadeu Mota que estiveram com ele na TI Mococa em 2003. Carolina Casão fez outras entrevistas, organizou-as e publicou-as em sua monografia de especialização (Casão 2007). Tivemos com o Sr. Augusto em outras oportunidades (2008 e 2010) e ele recontou a história da compra da terra de Mococa pelo seu avô Timotheo. 


\section{REFERÊNCIAS BIBLIOGRÁFICAS}

ALMEIDA, Aluisio de. 1947. Achêgas à biografia do Barão de Antonina. Revista do Arquivo Municipal de São Paulo CXI: 7-39.

BARBOSA, Luiz Bueno Horta. 1924. Carta aberta. Jornal do Commércio, 30 de dezembro de 1924.

BRASIL. "Regulamento das colônias indígenas do anno de 1857 - Províncias do Paraná e Mato Grosso". 25/04/1857. Boletim do Arquivo do Paraná 3(2/3): 66-74.

BROTERO, Francisco Brotero. s/d. Barão de Antonina. Apontamentos genealógicos. São Paulo: Escolas Profissionais Salesianas.

CARMACK, Robert M. 1972. "Ethnohistory: a reviewof its developement definitions, methodos, and aims". Annual Review of Anthropology 1: 227-246.

CARNEIRO, Davi. 1942. O Paraná na história militar do Brasil. Curitiba: Tip. João Haupt.

CASÃO, Carolina D. C. 2007. Produção e reprodução cultural na Terra Indígena Mococa: os Kaingang e suas relações com a natureza. Monografia de Especialização em Sociologia. Londrina, PR: Universidade Estadual de Londrina.

CAVALCANTI, José B. 1924. Exposição sobre as terras da povoação de S. Jeronymo, apresentada ao Miguel Calmon du Pin e Almeida. Rio de Janeiro: Imprensa Nacional.

CHICHORRO, Manuel da Cunha A. C. 1873. "Memória em que se mostra o estado econômico militar e político da Capitânia de São Paulo, quando do seu governo tomou posse a 8/12/1814". RIHGB, 36: 197-232.

CHMYZ, Igor. 1976. "Nota prévia sobre o sítio PR PG 1: Abrigo-sob-rocha Cambiju". Revista de Estudos Brasileiros. 1: 231-246.

1977. "Pesquisas paleoetnográficas efetuadas no vale do rio Paranapanema, Paraná, São Paulo". Boletim de Psicologia e Antropologia. Universidade Federal do Paraná, 5: 1-248.

1983. Sétimo relatório das pesquisas realizadas na área de Itaipu (1981/3). Curitiba: Convênio Itaipu-IPHAN, v. 7. Projeto Arqueológico Itaipu.

; CHMYZ, João Carlos Gomes. 1986. "Datações radiométricas em áreas de salvamento arqueológico no Estado do Paraná". Revista do Centro de Estudos e Pesquisas Arqueológicas, 5: 69-77.

; SGANZERLA, Eliane Maria; VOLCOV, Jonas Elias; BORA, Eloi; CECCON, Roseli Santos. 2008. "A arqueologia da área da LT 750kV Ivaiporã-Itaberá III, Paraná - São Paulo". Arqueologia - Revista do Centro de Estudos e Pesquisas Arqueológicas/UFPR, 5, 1-305.

COLOMBINA, Francisco Tosi. 1974 [1753]. Descobrimento das terras do Tibagi. Maringá: Universidade Estadual de Maringá.

CUNHA, Manuela Carneiro. 1987. Os direitos dos índios: ensaio e documentos. São Paulo: Brasiliense. 1992. Legislação indigenista do século XIX. São Paulo: Edusp.

ELLIOT, John Henrique. 1848. "Itinerário das viagens exploradoras pelo Sr. Barão de Antonina para descobrir uma via de communicação entre o porto da villa de Antonina e o baixo-Paraguay na província de Mato-Grosso: feitas nos annos de 1844 a 1847 pelo sertanista o Sr. Joaquim Francisco Lopes e descriptas pelo Sr. João Henrique Elliott". R. Inst. Hist. Geogr. Bras. 10: 53-177.

FRANCO. Arthur Martins. 1936. "Frei Timotheo de Castelnovo". Revista do Círculo de Estudos Bandeirantes. 1(3) 
FRIGO, Frei Adelino. 1995. Memória de um herói. Londrina: Grafmark.

DIÁRIO DE CURITIBA. 13 de setembro de 1922.

LAMING-EMPERAIRE, Annete. 1968. "Missions archéologiques françaises au Chili Austral et au Brésil Méridional". Journal de la Société des Américanistes, 57: 77-99.

LITTLE, Paul. 2002. "Territórios sociais e povos tradicionais no Brasil: por uma antropologia da territorialidade". UnB - Série Antropológica 322.

MELIÁ, Bartolomeu; GRUNBERG, George; GRUNBERG, Friedl. 1976. Etnografia Guarani del Paraguay contemporaneo: los Paí-Tavyterã. Suplemento Antropológico - Universidad Católica. Asunción, 11 (1-2).

MERCER, Edmundo Alberto; MERCER, Luiz Leopoldo. 1977 [1934]. História de Tibagi. Curitiba: Objetiva Artes Gráficas.

MOTA, Lúcio Tadeu. 1997. A guerra de conquista nos territórios dos índios Kaingang do Tibagi. Revista de História Regional 2(1): 187-207.

1998. O instituto histórico e geográfico brasileiro e as propostas de integração das comunidades indígenas no Estado Nacional. Revista Diálogos, 2: 149-175.

2000a. As colônias indígenas no Paraná provincial. Curitiba: Aos Quatro Ventos.

2000b. Os índios Kaingang e seus territórios nos campos do Brasil meridional na metade do século passado. In: MOTA, L. T.; NOELLI, F. S.;

2009. As guerras dos índios Kaingang: a história épica dos índios Kaingang no Paraná (1769-1924). $2^{\mathrm{a}}$ ed. Maringá: Eduem.

2012. História do Paraná - Relações sóciocuturais: da pré-história à economia cafeeira. Maringá: Eduem. 2014. "A presença indígena no vale do Rio Tibagi/PR no início do século XX". Antíteses, 7: 358-391.

; BONNICl, Thomas. 2008. "A história do vale do rio Tibagi. Texto inédito do engenheiro inglês Thomas $\mathrm{P}$. Bigg-Wither". In: G. Arruda (org.) A natureza dos rios: história, memória e territórios. Curitiba: Editora UFPR.

; NOELLI, Francisco. 1999. A pré-história da região onde se encontra Maringá, Paraná. IN: DIAS, R. B.; GONÇALVES, J. H. R. (Org.) Maringá e o Norte do Paraná. Maringá: EDUEM. p. 05-19.

; NOELLI, Francisco.1999. "Exploração e guerra de conquista dos territórios indígenas nos vales dos rios Tibagi, Ivaí e Piquiri". R.B. Dias; J.H.R. Gonçalves (orgs.). Maringá e o Norte do Paraná. Maringá: EDUEM.

; NOVAK, Éder. 2008. Os Kaingang do rio Ivaí - PR: história e relações interculturais. Maringá: Eduem.

NOELLI, Francisco. 2000. "A ocupação humana na região sul do Brasil: Arqueologia, debates e perspectivas - 1872 - 2000". Revista USP, 44: 218-269.

NOVAK, Éder da Silva. 2006. Tekohá e Emã: a luta das populações indígenas por seus territórios e a política indigenista no Paraná da Primeira República - 1889 a 1930. Dissertação (Mestrado). Maringá, PR: Universidade Estadual de Maringá.

ORLEANS, Frei Casimiro M. de. 1957. Pai dos Coroados. Curitiba: Max Roesner.

PARANÁ. 1915. Estado do Paraná - Coleção de Decretos e Regulamentos de 1915.

1978. Regulamento das colonias indígenas do anno de 1857 - Provincias do Paraná e Mato Grosso. 25/04/1857.

Boletim do Arquivo do Paraná. 3(2/3): 66-74. 
PARELLADA, Claudia. 2005. Estudo arqueológico no alto vale do rio Ribeira: área do gasoduto Bolívia-Brasil, trecho X, Paraná. 271p. Tese (Doutorado). São Paulo, SP: Universidade de São Paulo.

PAULA, José Maria de. 1944. Terra dos Índios. Rio de Janeiro: Ministério da Agricultura.

PRIMERIO, Frei Fidelis M. de. 1942. Capuchinhos em terras de Santa Cruz nos séculos XVII, XVIII e XIX. São Paulo: Livraria Martins.

RAMOS, Alcida R. 1986. Sociedades Indígenas. São Paulo: Ática.

SEEGER, Anthony; VIVEIROS DE CASTRO, Eduardo. 1978. Terras e territórios indígenas do Brasil. Encontros com a Civilização Brasileira. 12: 3-4.

TAUNAY, Affonso de E. 1955. A grande vida de Fernão Dias Paes. Rio de Janeiro: J. Olympio.

TOMMASINO, Kimiy. 1995. A história dos Kaingang da bacia do Tibagi: uma sociedade Jê meridional em movimento. Tese (Doutorado). São Paulo, SP: Universidade de São Paulo.

2000. "Território e territorialidade Kaingang: resistência cultural e historicidade de um grupo Jê". In: L.T. Mota; F.S. Noelli; K. Tommasino. (orgs.) Uri e Wãxi: estudos interdisciplinares dos Kaingang. $1^{\text {a }}$ ed. Londrina: Eduel.

TRIGGER, Bruce G. 1982. Ethnohistory: problems and prospects. Ethnohistory, 29(1): 1-19.

VACA, Alvar Nunes Cabeza de. [1555] 1987. Naufrágios e Comentários. Porto Alegre, LPM.

VAL FLORIANA, Mansueto Barcatta de. 1920. " Diccionarios Kainjgang-Portuguez e Portuguez-Kainjgang composto pro Frei Mansueto Barcatta de Val Floriana da ordem dos missionários capuchinhos do estado de São Paulo". Revista do Museu Paulista, 12:1-392.

VOEGELIN, Erminie W. 1954. "A Note from the Chairman". Ethnohistory 1 (1): 1-3. .1954. "An Ethnohistorian's View point". Ethnohistory 1 (2):166-171.

WACHOWICZ, Ruy Christovam. 1987. Norte Velho, Norte Pioneiro. Curitiba: Gráfica Vicentina

WISSENBACH, Maria C. C. 1995. "Desbravamento e catequese na constituição da nacionalidade brasileira: as expedições do Barão de Antonina no Brasil meridional. Revista Brasileira de História 15(30): 137-155. 


\section{Desiguais e combinados: índios e brancos no vale do RioTibagi - PR na primeira metade do século XX}

\section{RESUMO}

Este artigo demonstra e analisa o processo de desterritorialização das áreas indígenas na bacia hidrográfica do rio Tibagi no Paraná. Enfatiza-se as primeiras demarcações de terras para grupos indígenas no início do século XX e as reduções destes territórios, culminadas em 1949. Atualmente são cinco Terras Indígenas no rio Tibagi: Apucaraninha, São Jerônimo, Barão de Antonina, Mococa e Queimadas, onde vivem em torno de 3.500 índios, a maioria da etnia Kaingang, mas há também Guarani, Xocleng e Xetá. Historicamente estes grupos indígenas travaram inúmeras batalhas para a defesa dos seus territórios, entrecruzando suas estratégias políticas frente à política indigenista oficial. Sendo sujeitos de sua própria história, souberam agir dentro de diferentes contextos históricos, mantendo-se enquanto populações diferenciadas e permanecendo donos de uma parte dos territórios outrora ocupados.

PALAVRAS-CHAVE: relações sócioculturais; populações indígenas; rio Tibagi; fronteiras e populações; política Indigenista.

\section{Unequal and combined: indians and white settlers in the Tigabi River Valley - Paraná in the first half of the 20th century}

\section{ABSTRACT}

This article demonstrates and analyses the process of dispossession of indigenous areas in the basin of Tibagi River, emphasizing the first demarcation of indigenous lands in the early twentieth century and the reductions of this territory, culminated in 1949. Currently there are five indigenous along the Tibagi River: Apucaraninha, São Jerônimo, Barão de Antonina, Mococa and Queimadas. The total population sums up to 3,500 Indians, mostly Kaingang, but there are also Guarani, Xetá and Xocleng. Historically these indigenous groups fought numerous battles to defend their territories, entangling their own political strategies with the official Indian national policy. Being the subjects of their own history, the Kaingang managed to act within different historical contexts in order to keep their own identity and to remain the owners of part of their original territory.

KEY WORDS: sociocultural relations; indigenous peoples; Tibagy river; borders and populations; indigenous policy. 


\section{ANEXO 1}

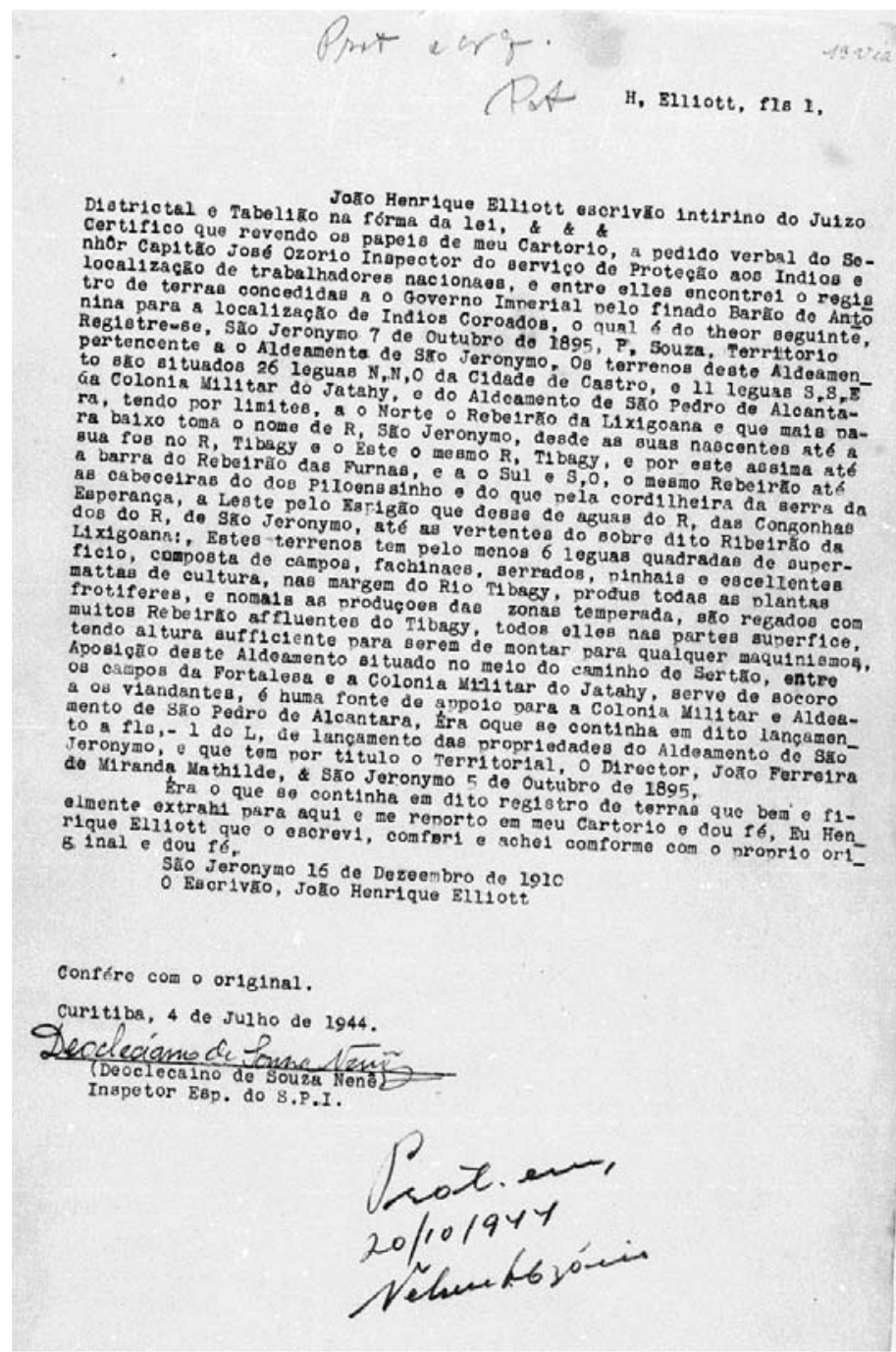

Esse documento está no acervo do Museu do Índio no Rio de Janeiro, Filme 75 fotogramas, 2.035. Em julho de 1944, o Sr. Deocleciano de Souza Nenê, então inspetor especial do SPI, encontrou o documento em meio aos papéis da $7^{a}$ Inspetoria Regional, dele fez uma cópia que foi para o arquivo do Museu do Índio e do qual reproduzimos abaixo devido a sua importância para o entendimento da história dos Kaingang de São Jeronimo da Serra no Paraná. 


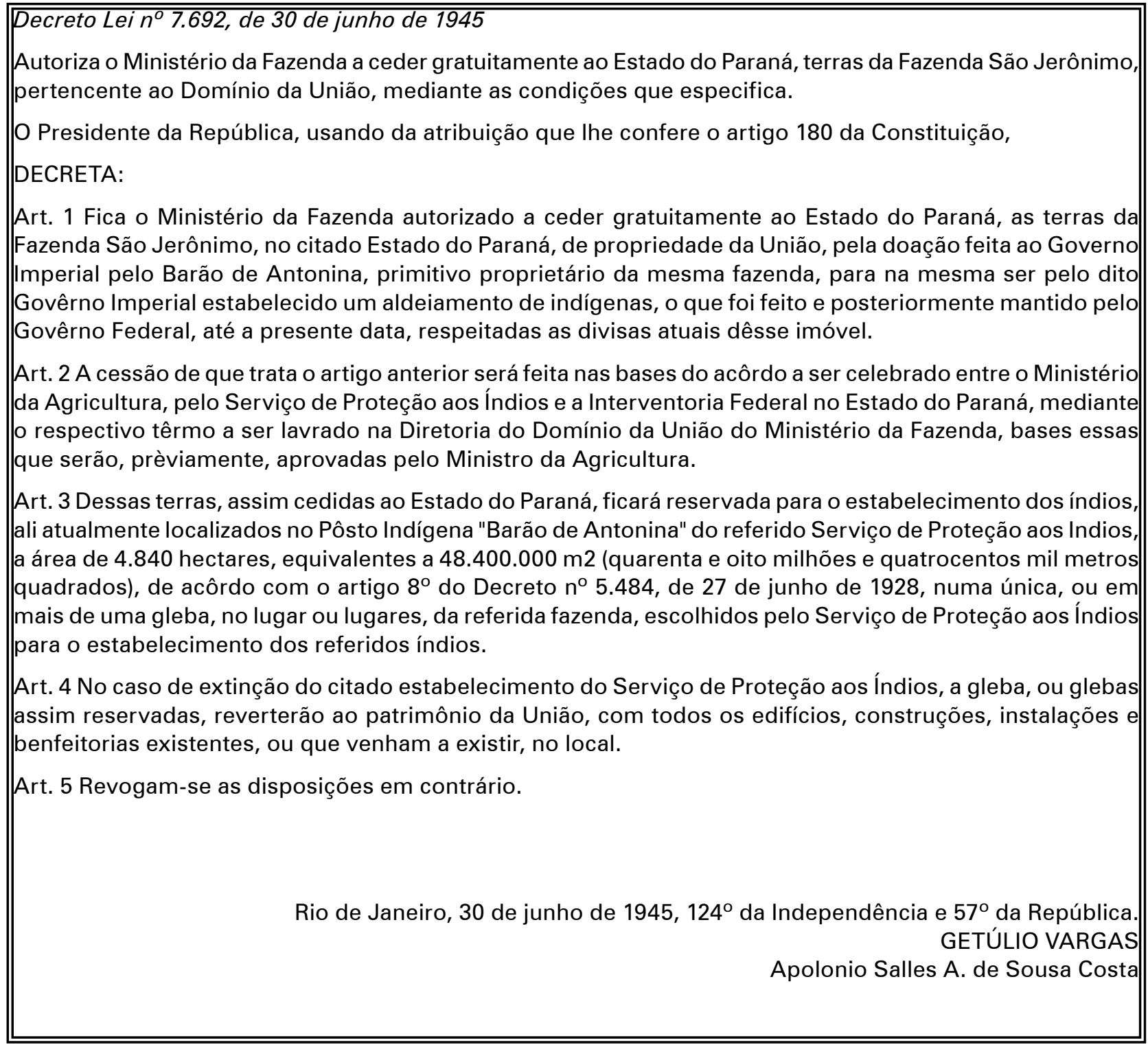

